\title{
The Effect of Hypoxia on the Expression of CXC Chemokines and CXC Chemokine Receptors-A Review of Literature
}

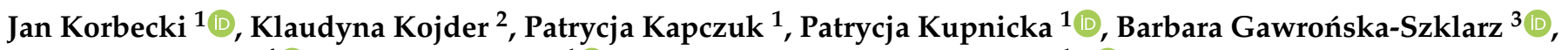 \\ Izabela Gutowska ${ }^{4} \mathbb{D}$, Dariusz Chlubek ${ }^{1} \mathbb{D}$ and Irena Baranowska-Bosiacka ${ }^{1, * \mathbb{B}}$ \\ 1 Department of Biochemistry and Medical Chemistry, Pomeranian Medical University in Szczecin, \\ Powstańców Wielkopolskich 72 Av., 70-111 Szczecin, Poland; jan.korbecki@onet.eu (J.K.); \\ patrycja.kapczuk@pum.edu.pl (P.K.); patrycjakupnicka@o2.pl (P.K.); dchlubek@pum.edu.pl (D.C.) \\ 2 Department of Anaesthesiology and Intensive Care, Pomeranian Medical University in Szczecin, \\ Unii Lubelskiej 1, 71-281 Szczecin, Poland; klaudynakojder@gmail.com \\ 3 Department of Pharmacokinetics and Therapeutic Drug Monitoring, Pomeranian Medical University in \\ Szczecin, Powstańców Wielkopolskich 72 Av., 70-111 Szczecin, Poland; \\ barbara.gawronska-szklarz@pum.edu.pl \\ 4 Department of Medical Chemistry, Pomeranian Medical University in Szczecin, Powstańców Wlkp. 72 Av., \\ 70-111 Szczecin, Poland; izagut@poczta.onet.pl \\ * Correspondence: ika@pum.edu.pl; Tel.: +48-914661515
}

Citation: Korbecki, J.; Kojder, K.; Kapczuk, P.; Kupnicka, P.; Gawrońska-Szklarz, B.; Gutowska, I.; Chlubek, D.; Baranowska-Bosiacka, I. The Effect of Hypoxia on the Expression of CXC Chemokines and CXC Chemokine Receptors-A Review of Literature. Int. J. Mol. Sci. 2021, 22, 843. https://doi.org/ $10.3390 /$ ijms 22020843

Received: 9 December 2020

Accepted: 12 January 2021

Published: 15 January 2021

Publisher's Note: MDPI stays neutral with regard to jurisdictional claims in published maps and institutional affiliations.

Copyright: (c) 2021 by the authors. Licensee MDPI, Basel, Switzerland. This article is an open access article distributed under the terms and conditions of the Creative Commons Attribution (CC BY) license (https:/ / creativecommons.org/licenses/by/ $4.0 /)$.

\begin{abstract}
Hypoxia is an integral component of the tumor microenvironment. Either as chronic or cycling hypoxia, it exerts a similar effect on cancer processes by activating hypoxia-inducible factor- 1 (HIF-1) and nuclear factor (NF- $\mathrm{B}$ ), with cycling hypoxia showing a stronger proinflammatory influence. One of the systems affected by hypoxia is the CXC chemokine system. This paper reviews all available information on hypoxia-induced changes in the expression of all CXC chemokines (CXCL1, CXCL2, CXCL3, CXCL4, CXCL5, CXCL6, CXCL7, CXCL8 (IL-8), CXCL9, CXCL10, CXCL11, CXCL12 (SDF-1), CXCL13, CXCL14, CXCL15, CXCL16, CXCL17) as well as CXC chemokine receptorsCXCR1, CXCR2, CXCR3, CXCR4, CXCR5, CXCR6, CXCR7 and CXCR8. First, we present basic information on the effect of these chemoattractant cytokines on cancer processes. We then discuss the effect of hypoxia-induced changes on CXC chemokine expression on the angiogenesis, lymphangiogenesis and recruitment of various cells to the tumor niche, including myeloid-derived suppressor cells (MDSCs), tumor-associated macrophages (TAMs), tumor-associated neutrophils (TANs), regulatory $\mathrm{T}$ cells $\left(\mathrm{T}_{\text {regs }}\right)$ and tumor-infiltrating lymphocytes (TILs). Finally, the review summarizes data on the use of drugs targeting the CXC chemokine system in cancer therapies.
\end{abstract}

Keywords: CXC chemokine; cancer; tumor; hypoxia; hypoxia-inducible factor; cycling hypoxia; HIF-1 $\alpha$; NF- $\mathrm{B}$; SDF-1; IL-8

\section{Introduction}

Growing standards of living and advances in medicine in many countries have resulted in increased life expectancies. This has led to the spread of other diseases, particularly "civilization diseases" which are associated with lifestyle and environmental pollution, and diseases related to old age. One of these is cancer, a major problem in developed countries [1] and the cause of 55.9 million deaths worldwide in 2017 [1,2] - a 25\% increase when compared to 2007 [2]. This trend has led to the intensification of efforts aimed at developing more effective therapeutic approaches.

The last 15 years have seen an increasing interest in the tumor microenvironment-a set of factors affecting a cancer cell in a tumor [3]. One of these are noncancer cells recruited to a tumor niche, with the recruitment process depending on factors secreted from cells already located in the tumor niche. These include factors changing the recruited cell into a tumor-associated cell-i.e., transforming the cell into an element which supports cancer processes $[4,5]$. Both cancer and noncancer cells secrete a number of factors which 
shape the tumor microenvironment, including chemoattractant cytokines, also known as chemokines [6,7]. Changes in the expression of chemokines affect the recruitment of cells to the tumor niche, angiogenesis and migration of cancer cells. For this reason, understanding the role of chemokines in cancer processes seems crucial for understanding the functioning of a tumor [7]. There is a lack of research on the influence of hypoxia, i.e., tumor-specific conditions, on CXC chemokines and so the aim of this review was to collect all literature data on the influence of hypoxia on the expression of CXC chemokines in a tumor.

\section{Hypoxia in a Tumor}

Tumors are associated with two kinds of hypoxia-chronic hypoxia (also known as continuous or noninterrupted hypoxia) and cycling hypoxia (intermittent or transient hypoxia). Chronic hypoxia is a persistent reduction in oxygen levels that results from an excessive distance between cells and vascular vessels whose growth cannot keep up with the rapid growth of the tumor [8]. Cycling hypoxia has cyclic episodes of oxygen deficiency interspersed with periods of reoxygenation [9]—a result of structural abnormalities in the vascular vessels, particularly the lack of a conventional hierarchy (Figure 1) [10,11]. In such vessels, the blood flow often changes route, resulting in hypoxia in some areas of the tumor. Then, when the blood flow changes its route again, some areas become reoxygenated. One such cycle of hypoxia lasts from several minutes [12] to $4 \mathrm{~h} \mathrm{[13],} \mathrm{depending} \mathrm{on} \mathrm{the} \mathrm{selected}$ research model.

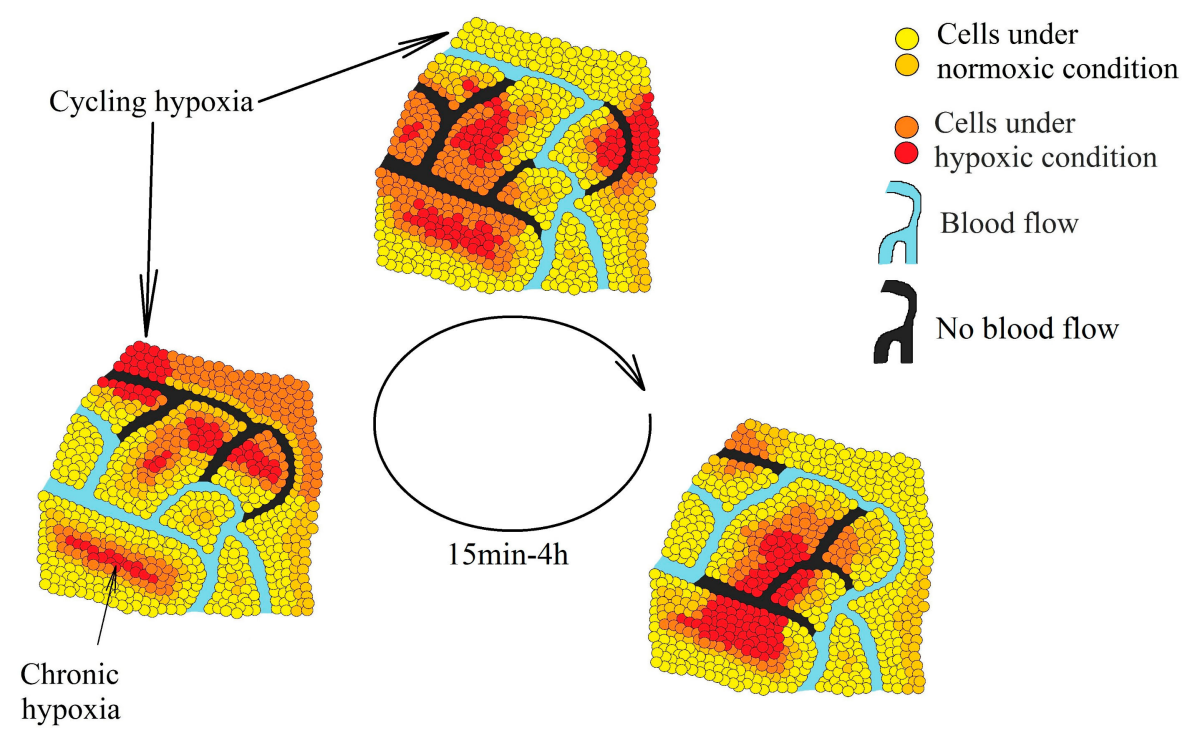

Figure 1. Two types of hypoxia in a tumor: chronic hypoxia associated with an excessive distance from the blood vessels and cycling hypoxia associated with changes in the blood flow in the vessels inside the tumor which lead to periodic oxygen deficiencies in various parts of the tumor.

Both types of hypoxia change the expression of similar genes [14] as they activate the same transcription factors-hypoxia-inducible factors (HIFs) and nuclear factor $\mathrm{kB}$ (NF-kB). The mechanisms of activation, however, are different. In chronic hypoxia, the main role is played by a reduction in oxygen levels which triggers a drop in the activity of oxygen-dependent enzymes [15]. In cycling hypoxia, transcription factors are activated mainly by reactive oxygen species (ROS) [16,17].

Hypoxia-inducible factors (HIF-1, HIF-2 and HIF-3) exhibit transcriptive activity that is regulated by the proteolytic degradation of subunit $\alpha$ (HIF- $1 \alpha$ and HIF-2 $\alpha$ ) [18-20]. This degradation occurs due to the hydroxylation of HIF- $1 \alpha$ and HIF- $2 \alpha$ in proline residues by prolyl hydroxylase (PHD), which leads to the ubiquitination by von Hippel-Lindau protein (pVHL) and then to proteolytic degradation of these HIF- $\alpha$ subunits [21]. PHD are oxygendependent enzymes (Figure 2) [15]. For this reason, in chronic hypoxia, there is a decrease in PHD activity which leads to a decrease in HIF- $\alpha$ hydroxylation of proline residues and a 
decrease in proteolytic degradation of these HIF subunits. HIF- $1 \alpha$ reaches the maximum level in a cell after $6 \mathrm{~h}$ of chronic hypoxia, whereas HIF-2 $\alpha$ reaches this after $48 \mathrm{~h}$ [22]. The expressions of PHD2 and PHD3 are increased by HIF-1 and HIF-2 [23-26], which makes HIF- $\alpha$ degrade more intensely during reoxygenation. In turn, cycling hypoxia increases the level of ROS, which oxidizes the iron atoms in PHD and thus reduces the activity of these enzymes [16,27]. This leads to a drop in the hydroxylation of proline residues on HIF- $\alpha$, which means that HIF- $\alpha$ is no longer degraded but accumulated instead. The increase in HIF- $1 \alpha$ levels during cycling hypoxia also occurs via other pathways-for example, the ROS-dependent activation of protein kinase A (PKA) phosphorizes this HIF-1 subunit thereby increasing its stability $[28,29]$. A ROS-dependent increase in calcium ion concentration in cytoplasm, the activation of protein kinase $\mathrm{C}$ (PKC) and the mammalian target of rapamycin (mTOR) are also significant [30]. In cycling hypoxia, the accumulation of HIF- $1 \alpha$ increases with the successive cycles of oxygen deficiency [31]. However, this protein is completely degraded during episodes of reoxygenation [31].

\section{A Normoxia}

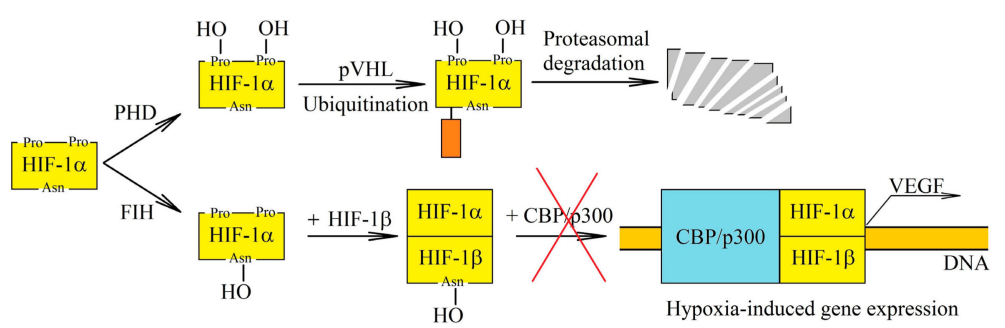

\section{B Moderate hypoxia}

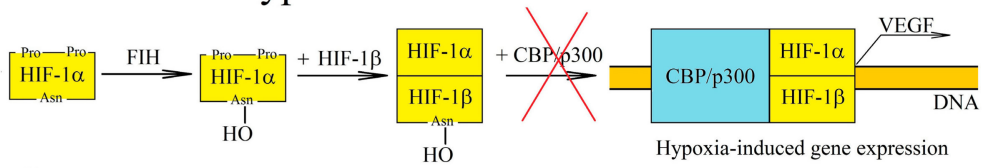

\section{Hypoxia}

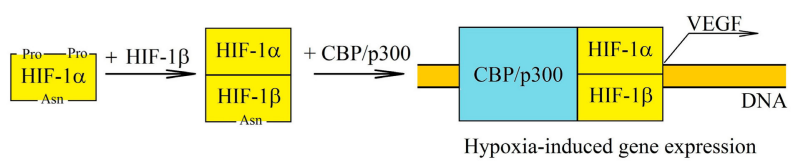

Figure 2. Regulation of hypoxia-inducible factor-1 (HIF-1) transcriptional activity at various oxygen concentrations. (A) In normoxia, HIF-1 $\alpha$ is hydroxylated by the oxygen-dependent enzymes prolyl hydroxylase (PHD) and factor inhibiting HIF (FIH). The PHD-catalyzed reaction leads to proteasomal degradation of HIF- $1 \alpha$. In turn, hydroxylation by FIH prevents interaction of HIF-1 with the $\mathrm{CBP} /$ p300 coactivator. (B) PHD and FIH require different concentrations of oxygen for their activity and so, in moderate hypoxia, PHD activity decreases while FIH retains its functions. Accumulation of HIF- $1 \alpha$ occurs, but due to hydroxylation by FIH, there is no interaction between HIF- 1 and the $\mathrm{CBP} /$ p300 coactivator, and thus genes dependent on this coactivator are not expressed. (C) In hypoxia, the activities of oxygen-dependent enzymes are reduced. For this reason, HIF- $1 \alpha$ is not hydroxylated by PHD or by FIH. This subunit begins to form a transcription factor with HIF-1 $\beta$, which is responsible for inducing the transcription of hypoxia-dependent genes.

The regulation of HIF transcriptional activity also involves factor inhibiting HIF (FIH), an enzyme which causes the hydroxylation of asparagine residue [32] and thus disrupts the interaction of HIF- $\alpha$ with the CBP/p300 coactivator [33,34]. In this way, FIH blocks the expression of HIF/CBP/p300-dependent genes. As FIH is an oxygen-dependent enzyme [35], its activity is reduced by chronic hypoxia and ROS which oxidize the iron atom-a part of the enzyme that is critical for its function [32]. FIH requires a much lower level of oxygen for its activity than PHD ( $K_{m}$ for FIH is $90 \mu \mathrm{M}$, whereas for PHD it is 
$230-250 \mu \mathrm{M})[15,35,36]$. For this reason, in moderate hypoxia, the HIF pathway is inhibited by FIH but not by PHD.

Both types of hypoxia also activate NF- $\mathrm{kB}$. In chronic hypoxia, this activation is dependent, among other things, on a reduction in the amount of oxygen and the ensuing reduction in the activity of PHD, an enzyme that inhibits the activation of NF- $\mathrm{KB}$ and HIF $[37,38]$. The activation of NF- $\mathrm{kB}$ in chronic hypoxia also depends on the activation of calcium/calmodulin-dependent kinase 2 (CaMK2) [39]. In contrast, in cycling hypoxia, NF- $\mathrm{KB}$ activation is ROS-dependent $[17,40,41]$.

In chronic hypoxia, the activation of NF- $\mathrm{KB}$ results in an increased expression of HIF- $1 \alpha$ and therefore has a significant effect on the HIF activation pathway [42,43]. This is related to the occurrence of the NF- $\mathrm{kB}$ binding site in the HIF1A gene promoter. For this reason, during chronic hypoxia, the expression of genes is directly induced by NF$\kappa B$. There is also an increase in the expression of genes directly dependent on HIF- $1 \alpha$ but these are also indirectly dependent on NF- $\mathrm{kB}$ during chronic hypoxia. Therefore, in order to acquire a detailed insight into the mechanism which induces the expression of a given gene by chronic hypoxia, it is necessary to demonstrate the occurrence and investigate the functionality of the hypoxia responsive element (HRE) binding HIF or the NF- $\mathrm{kB}$ binding site. Importantly, chronic hypoxia and inflammation exclude each other by various mechanisms [44,45], and so chronic hypoxia reduces the inflammatory response. On the other hand, some proinflammatory genes are induced by both chronic hypoxia and inflammation [46]. Cycling hypoxia is more proinflammatory than chronic hypoxia $[41,47,48]$. This is related to the activation of NF- $\mathrm{kB}$ by ROS $[17,40,41]$. For this reason, NF- $\mathrm{KB}$ plays a more important role in gene expression during cycling hypoxia than in chronic hypoxia.

Hypoxia significantly changes the functioning of the tumor. Its proapoptotic effect on cells results in a selection of cells in terms of apoptosis resistance, a process which is important at the beginning of tumor development and results in the presence of cancer cells with a p53 dysfunction in the tumor [49]. Hypoxia also participates in the progression of cancer at further stages of the process. In particular, hypoxia is important in the functioning of cancer stem cells (CSCs) [50-55], which increase the resistance of the tumor to anticancer therapy. Hypoxia also causes cancer cell migration, invasion and metastasis, partly due to hypoxia causing the epithelial-to-mesenchymal transition (EMT) [55-59]. For this reason, areas of chronic hypoxia are often associated with neoplastic cell metastasis.

Tissues respond to oxygen deficiency by developing new blood vessels. In this way, hypoxia increases the expression of proangiogenic factors such as vascular endothelial growth factor (VEGF)-A [60,61], platelet-derived growth factor subunit A (PDGF-A), transforming growth factor- $\beta$ (TGF- $\beta$ ) and angiopoietin-like 4 (ANGPTL4) [62]. Hypoxia also participates in tumor immune evasion by polarizing macrophages to the M2 phenotype which silences the immune response [63]. It also protects cancer cells by impairing the function of NK cells $[64,65]$ and increasing the production of immunosuppressive proteins such as indoleamine 2,3-dioxygenase (IDO), human leukocyte antigen-G (HLA-G), programmed death-ligand 1 (PD-L1) and metabolites such as adenosine $[66,67]$. The hypoxia-induced acidosis of the cancer microenvironment, which is caused by an increased production and secretion of lactate is also important [66,68]. Lactate causes tumor immune evasion and neoplastic cell migration.

Hypoxia also affects the CXC chemokine system, which leads to changes in the level of these chemoattractant cytokines in the cancer microenvironment. CXC chemokines participate in the growth of the tumor due to a number of procancer properties.

HIF- $1 \alpha$ accumulation and increased HIF-1 transcriptional activity occurs in cancer cells even in normoxia. This is related to, among other things, mutations in the VHL gene which encodes pVHL, resulting in the loss of biological function of $\mathrm{pVHL}$, thereby reducing the degradation of HIF- $1 \alpha[69,70]$. Tumors also exhibit deletions of parts of the chromosome where the HIF1AN gene locus are located [71]. This gene encodes FIH-1, the enzyme responsible for inhibiting the transcriptional activity of HIF-1. Another way of activating the HIF-1 
pathway under normoxia is HIF- $1 \alpha$ phosphorylation [20] which leads to the increased stability of this protein and consequently, to HIF- $1 \alpha$ accumulation in cells and increased expression of HIF-1dependent genes. Enzymes performing such phosphorylation under normoxia include PKA activated by cAMP [72], phosphatidylinositol-4,5-bisphosphate 3-kinase (PI3K) [73,74], extracellular signal-regulated kinase (ERK) mitogen-activated protein kinase (MAPK) [75-77]. HIF-1 $\alpha$ is also phosphorylated by glycogen synthase kinase 3 which reduces the stability of this protein [77]. Apart from phosphorylation, other types of post-translational modifications also affect the activation of HIF-1 under normoxia. One of them is the deacetylation of HIF- $1 \alpha$ by sirtuin 1 (SIRT1), which leads to a decrease in HIF-1 transcriptional activity [78]. In addition to the post-translational modification, the activation of NF- $\mathrm{KB}$ in normoxia also increases the expression of HIF- $1 \alpha$, which is important for an increase in the activation of HIF-1 during inflammatory reactions [75]. The elevated activation of HIF-1 via these pathways in normoxia increases the expression of genes dependent on this transcriptional factor. Although there are no studies in this area that confirm it, it is possible that this mechanism is responsible for the increase in the expression of CXC chemokines and CXC chemokine receptors in normoxia.

\section{CXC Chemokines in Cancer}

CXC chemokines (also known as $\alpha$-chemokines) are a subfamily of chemotactic cytokines with a CXC motif at the N-terminus. Currently, we know 17 CXC chemokines [6,79], of which CXC motif chemokine ligand (CXCL) 15 is a murine CXC chemokine not found in humans [80]. As such, it is not mentioned in Table 1 which shows the procancer and anticancer properties of CXC chemokines. The chemokines from this subfamily activate the CXC motif chemokine receptors (CXCRs)1-8 (Table 1) [6,79,81-84]. The receptor for CXCL14 is not clearly established. It seems that CXCL14 is a CXCR4 antagonist [85]. However, subsequent studies have shown that CXCL14 may not directly affect CXCR4 [86]. Other studies have shown that the receptors for CXCL14 may be G-protein coupled receptor 85 (GPR85) [87], toll-like receptor (TLR)9 after the formation of a complex of CXCL14 with CpG oligodeoxynucleotide [88], and insulin-like growth factor I receptor (IGF-IR) [89].

Table 1. Human CXC chemokines and their effect on selected cancer processes.

\begin{tabular}{|c|c|c|c|c|}
\hline Official Name & Alternative Name & Receptor & $\begin{array}{l}\text { Effect on the Recruitment and Accumulation } \\
\text { of Cells into the Tumor Niche }\end{array}$ & $\begin{array}{l}\text { Effect on Angiogenesis } \\
\text { in a Tumor }\end{array}$ \\
\hline CXCL1 & GRO- $\alpha$ & CXCR2 & MDSC, MSC, TAN, $\mathrm{T}_{\text {reg }}$ & Angiogenic \\
\hline CXCL2 & GRO- $\beta$ & CXCR2 & MDSC, TAN & Angiogenic \\
\hline CXCL3 & GRO- $\gamma$ & CXCR2 & TAN & Angiogenic \\
\hline CXCL4 & PF-4 & CXCR3 & TIL, $\mathrm{T}_{\text {reg }}$ & $\begin{array}{c}\text { Angiostatic, } \\
\text { lymphangiostatic }\end{array}$ \\
\hline CXCL5 & ENA-78 & CXCR2 & MDSC, TAN & Angiogenic \\
\hline CXCL6 & GCP-2 & CXCR1, CXCR2 & TAN & Angiogenic \\
\hline CXCL7 & NAP-2 & CXCR2 & TAN, TAM & Angiogenic \\
\hline CXCL8 & IL-8 & CXCR1, CXCR2 & MSC, TAM, TAN, MDSC & Angiogenic \\
\hline CXCL9 & MIG & CXCR3 & TIL, $\mathrm{T}_{\text {reg }}$ & Angiostatic \\
\hline CXCL10 & IP-10 & CXCR3 & TIL, $\mathrm{T}_{\text {reg }}$ & Angiostatic \\
\hline CXCL11 & I-TAC & CXCR3, CXCR7 & TIL, $\mathrm{T}_{\text {reg }}$ & Angiostatic \\
\hline CXCL12 & SDF-1 & CXCR4, CXCR7 & MDSC, MSC, TAM, TAN, $\mathrm{T}_{\text {reg }}$ & $\begin{array}{c}\text { Angiogenic, } \\
\text { lymphangiogenic }\end{array}$ \\
\hline CXCL13 & BCA-1 & CXCR3, CXCR5 & MDSC, $\mathrm{T}_{\text {reg }}$ & Angiostatic \\
\hline CXCL14 & - & Unknown & CAF, TIL & Angiostatic \\
\hline CXCL16 & - & CXCR6, mCXCL16 & MSC, TAM, TIL, $\mathrm{T}_{\text {reg }}$ & Angiogenic \\
\hline CXCL17 & VCC-1 & CXCR8 & MDSC & Angiogenic \\
\hline
\end{tabular}

CAFs-cancer-associated fibroblasts; mCXCL16-membrane form CXCL16; MDSCs-myeloid-derived suppressor cells; MSCsmesenchymal stem cells; TAMs—-tumor-associated macrophages; TANs—tumor-associated neutrophils; $\mathrm{T}_{\text {regs }}$-regulatory T cells; TILstumor-infiltrating lymphocytes. 
CXC chemokines differ in their effect on angiogenesis. Seven of them (CXCL1, CXCL2, CXCL3, CXCL5, CXCL6, CXCL7, and CXCL8), with an additional ELR motif, mainly induce angiogenesis via CXCR2 [90-92]. VEGF activity also induces an increase in the expression of CXCL1 and CXCL8 in endothelial cells which enhances angiogenesis [93,94]. In contrast, CXCL4, CXCL9, CXCL10 and CXCL11 exert an angiostatic effect via their CXCR3 receptor [95-97]. One of them, CXCL4, has been shown to inhibit lymphangiogenesis, and so it can be inferred that the remaining CXCR3 ligands may have the same properties [97]. Another CXC chemokine, CXCL12, has angiogenic properties [98], and its actions are associated with VEGF, which increases the expression of CXCR4 (receptor of CXCL12) on endothelial cells, which in turn enhances the influence of CXCL12 on these cells [99]. CXCL12 induces an increase in VEGF expression in endothelial cells and thus indirectly enhances angiogenesis [100]. The activation of CXCR4 on a tumor cell also causes an increase in VEGF-C expression, leading to lymphangiogenesis [101]. Of the remaining CXC chemokines, CXCL13 interferes with the action of basic fibroblast growth factor (bFGF) which inhibits angiogenesis [102], CXCL14 also has angiostatic properties [103,104] and CXCL16 is an angiogenic chemokine [105], similar to CXCL17, a chemoattractant for monocytes and macrophages in which it increases the expression of VEGF-A [106].

CXC chemokines can cause a migration and invasion of tumor cells [7,107-109]. CXCR3 ligands either induce or inhibit migration of tumor cells, depending on whether CXCR3-A or CXCR3-B is activated [110,111]. CXCL14, depending on the research model, can have anticancer properties [112] and procancer properties [113].

Akin to other chemokines, CXC chemokines participate in the recruitment of cells to the tumor niche but what makes them different is their distinct ability to recruit tumorassociated neutrophils (TANs) [114-121]. Apart from TAN, they recruit myeloid-derived suppressor cells (MDSCs) [122-127], tumor-associated macrophages (TAMs) [122,128-130], mesenchymal stem cells (MSCs) [131-135] and regulatory T cells ( $\left.\mathrm{T}_{\text {regs }}\right)$ [136-146]. CXCL14 stimulates the autocrine growth of cancer-associated fibroblasts (CAFs) [147]. On the other hand, the ligands of CXCR3, and CXCL14 and CXCL16, cause tumor infiltration by anticancer tumor-infiltrating lymphocytes (TILs) [148-153] and thus show anticancer properties.

\section{Ligands of Receptors CXCR1 and CXCR2}

\subsection{The Effect of Hypoxia on the Expressions of CXCL1 and CXCL2}

The effect of hypoxia on the expressions of CXCL1 and CXCL2 depends on the type of cancer. For example, chronic hypoxia does not affect the expression of either chemokine in lung adenocarcinoma [154] but does increase the expression of CXCL1 in human acute myeloid leukemia cells [155], cervical cancer cells [156] and hepatocarcinoma cells [157]. The expressions of both CXCL1 and CXCL2 are increased by chronic hypoxia in PC-3 prostate cancer cells [14] but reduced in SK-OV-3 ovarian adenocarcinoma and WM793B melanoma cells. In colitis-associated colon cancer, the source of CXCL1 in hypoxia may be tumor epithelial cells which, in a reaction mediated by HIF-2, increase the expression of this chemokine in the tumor microenvironment resulting in the recruitment of monocytes to the tumor niche [158].

Cycling hypoxia increases the expression of both described chemokines (CXCL1 and CXCL2) in PC-3 prostate cancer cells and SK-OV-3 ovarian adenocarcinoma cells [14]. In contrast, it reduces the expression of CXCL1 and CXCL2 in WM793B melanoma cells [14]. However, in an in vivo model of Lewis lung carcinoma, cycling hypoxia increases the level of CXCL1 in a tumor [47].

Another important source of CXCL1 and CXCL2 in the hypoxic microenvironment may be TAMs and MDSCs, as chronic hypoxia increases CXCL1 and CXCL2 expression in macrophages [159] and MDSCs [160]. The most important factor increasing the expression of CXCL2 in TAMs is HIF-2 [161]. HIF-1-dependent expression of both chemokines in MDSCs is also significant [160]. This effect on the hypoxia-induced production of CXCL1 
and CXCL2 in TAMs and MDSCs may be associated with the presence of HRE in the promoters of the CXCL1 and CXCL2 genes $[158,162,163]$.

\subsection{Effect of Hypoxia on the Expression of CXCL3}

The promoter of the CXCL3 gene does not contain HRE [162]. For this reason, chronic hypoxia does not affect the expression of CXCL3 in lung adenocarcinoma cells [154] and WM793B melanoma cells [14]. Nevertheless, chronic hypoxia does increase the expression of CXCL3 in primary human monocytes [164], PC-3 prostate cancer cells [14] and MDSCs [160]. In MDSCs, this effect is dependent on HIF-1 [160], although this mechanism requires further research. HIF-1 may indirectly affect the expression of CXCL3. It can increase the expression of a protein or miRNA which directly regulates the expression of this chemokine. In contrast, chronic hypoxia reduces the expression of CXCL3 in primary rat astrocytes [165] and SK-OV-3 ovarian adenocarcinoma cells [14].

Cycling hypoxia also influences the expression of CXCL3. Its effect also depends on the cell line, inducing a reduction in expression in WM793B melanoma cells and an increase in PC-3 prostate cancer cells [14]. It may also have no effect at all, as in SK-OV-3 ovarian adenocarcinoma cells [14].

\subsection{Effect of Hypoxia on CXCL5 Expression}

Chronic hypoxia does not increase the expression of CXCL5 in breast cancer cells [166], cervical squamous carcinoma cells [167], lung adenocarcinoma cells [154] or MDSCs [160]. In contrast, chronic hypoxia increases the expression of this chemokine in primary human monocytes [164]. As well as this, the overexpression of HIF- $2 \alpha$ in murine articular chondrocytes increases the expression of CXCL5 which is related to the presence of HRE in the CXCL5 gene promoter [163]. The incompatibility of these results with those mentioned at the beginning of the paragraph may be due to differences between species. It is also possible that the expression of CXCL5 is dependent on HIF-2 but not on HIF-1. The indicated studies analyzed the changes in cells after $24 \mathrm{~h}$ of hypoxia-in such a long period of hypoxia, HIF-1 is activated, but HIF-2 is not. The maximum activation of HIF-2 only occurs after $48 \mathrm{~h}$ of chronic hypoxia [22].

\subsection{Effect of Hypoxia on CXCL6 Expression}

Chronic hypoxia increases the expression of CXCL6 in hepatocellular carcinoma cells [168], which induces the migration of these cancer cells. Chronic hypoxia also increases the expression of CXCL6 in PC-3 prostate cancer cells [14]. The induction of CXCL6 expression is HIF-1-dependent because the CXCL6 promoter contains HRE [162,168]. However, chronic hypoxia does not always enhance the expression of CXCL6 as it can also reduce it in primary human monocytes [164] and HeLa cervical cancer cells [169]. Chronic hypoxia has no effect on the expression of this chemokine in breast cancer cells [166], the HepG2 hepatocarcinoma cell line [157] and lung adenocarcinoma cells [154].

In turn, cycling hypoxia increases the expression of CXCL6 in PC-3 prostate cancer cells [14].

\subsection{Effect of Hypoxia on CXCL7 Expression}

Chronic hypoxia increases CXCL7 expression in cervical cancer cells [169] and primary rat astrocytes [165]. The overexpression of HIF-2 $\alpha$ increases the expression of this chemokine in murine articular chondrocytes [163]. In contrast, chronic hypoxia does not alter CXCL7 expression in HepG2 hepatocellular carcinoma cells [157] and lung adenocarcinoma cells [154].

\subsection{Effect of Hypoxia on CXCL8 Expression}

A tumor contains areas which are distant from blood vessels and characterized by chronic hypoxia, acidosis and cell necrosis. These areas show increased expression of CXCL8 as demonstrated by in vivo studies in human melanoma [170,171], human pan- 
creatic cancer [172] and ovarian carcinoma [173]. The observed effect depends on hypoxia $[172,174,175]$ and the acidosis of this microenvironment $[172,176]$. Chronic hypoxia does not alter CXCL8 expression in some cells, such as breast cancer cells [177], lung adenocarcinoma cells [154], primary hepatocytes [178] and uveal melanoma cells [179].

An increase in CXCL8 expression in melanoma cells [180], ovarian carcinoma $[173,181]$, pancreatic cancer [182] and rhabdomyosarcoma [183] in chronic hypoxia is dependent on the activation of activating protein-1 (AP-1) and NF- $\mathrm{kB}$ - in particular, NF- $\mathrm{kB}$ p65, NF- $\mathrm{kB}$ p50 and c-Jun [173]. The increase in CXCL8 expression in these tumor cells is independent of HIF-1 [173,183] and nuclear factor-interleukin-6 (NF-IL-6) [173].

As with all the aforementioned chemokines, the mechanism of an increase in CXCL8 expression in chronic hypoxia depends on the type of tumor. In glioblastoma multiforme cells [184], an increase in CXCL8 expression in chronic hypoxia is AP-1-dependent but not NF- $\mathrm{BB}$-dependent. In contrast, in some bladder cancer lines, it is associated with the activation of NF-KB but not AP-1 [185]. In turn, in hepatocellular carcinoma cells, an increase in the expression of CXCL8 in chronic hypoxia is dependent on the activation of HIF-1 and the effect of this transcription factor on NF- $\mathrm{KB}[186,187]$. In other types of cancer, the effect of HIF-1 may differ-for example, in colon cancer cells, chronic hypoxia increases the expression of CXCL8 via NF- $\mathrm{kB}$ [188]. However, the activation of HIF-1 inhibits the effect of NF-KB on the expression of CXCL8 [188].

Hypoxia can also indirectly increase the expression of CXCL8 in glioblastoma multiforme cells by a HIF-1-dependent increase in the expression of ZNF395, a transcriptional factor that supports the increase in CXCL8 expression [189]. In melanoma cells, chronic hypoxia degrades Tip110 by increasing the ubiquitination of this protein [190]. The decrease in the level of Tip110 causes an increase in CXCL8 mRNA stability, which leads to an increase in CXCL8 expression [191]. In colon cancer, chronic hypoxia intensifies the expression of dual specificity phosphatase 2 (DUSP2), a nuclear phosphatase which reduces the activation of MAPK cascades [192,193]. The reduction in the expression of DUSP2 increases the activation of MAPK cascades in chronic hypoxia and thus elevates the expression of CXCL8. In turn, in lung adenocarcinoma cells, chronic hypoxia causes a change in the substrate specificity of dihydrodiol dehydrogenase which then starts to produce prostaglandin $\mathrm{F}_{2 \alpha}\left(\mathrm{PGF}_{2 \alpha}\right)$, which increases the expression of CXCL8 [194]. However, it needs to be remembered that the mechanisms mentioned in this paragraph are not necessary for the induction of CXCL8 expression in tumor cells by chronic hypoxia and that they only enhance the influence of chronic hypoxia in terms of the expression of this chemokine.

Cycling hypoxia also increases the expression of CXCL8, although its effect is dependent on the research model. In PC-3 prostate cancer cells, both types of hypoxia induce a similar increase in the expression of CXCL8 [14]. In SK-OV-3 ovarian adenocarcinoma cells, cycling hypoxia-unlike chronic hypoxia-increases the expression of CXCL8 [14]. In human aortic endothelial cells, cycling hypoxia increases the expression of CXCL8 more than chronic hypoxia [195]. In neutrophils, cycling hypoxia increases the expression of CXCL8 and the receptor of this chemokine CXCR2, which reduces the spontaneous apoptosis of these cells $[196,197]$. This may be significant in the recruitment and accumulation of TANs into the tumor niche. The effect of cycling hypoxia on CXCL8 expression is associated with increased ROS levels and greater NF-kB activation than in chronic hypoxia [198,199].

TAMs may also be an important source of CXCL8 in the hypoxic microenvironment. However, there are no studies showing in vivo effects of hypoxia on CXCL8 expression in TAMs. The expression of this chemokine in TAMs may be increased by factors from tumor cells [200]. Studies on monocyte-derived macrophages have shown that the expression of this chemokine in these cells may be increased by chronic hypoxia $[159,201]$ via AP-1 activation [201]. HIF-1 and HIF-2 are no less important in this process [159], influencing the activation of NF- $\mathrm{KB}$ and thus increasing the expression of CXCL8. However, studies on (i) phorbol 12-myristate 13-acetate (PMA)-differentiated THP-1 macrophages and (ii) PMA-differentiated THP-1 macrophages, polarized by lipopolysaccharides (LPSs) and 
interferon- $\gamma($ IFN- $\gamma)$, have shown that chronic hypoxia does not affect the expression of CXCL8 in these cells [202]; however, cycling hypoxia increases the expression of this chemokine in these THP-1 macrophages, in a process dependent on the activation of c-Jun $\mathrm{N}$-terminal kinase (JNK) MAPK and NF- $\mathrm{KB}$ [202].

The expression of CXCL8 in endothelial cells is an important issue in cancer. VEGF secreted by cells in the tumor niche causes an increase in CXCL1 and CXCL8 expressions in endothelial cells, in a process important to angiogenesis and the migration of cancer cells $[93,94]$. Chronic hypoxia changes the expression of CXCL8 in endothelial cells, although this effect is dependent on the research model. For example, an increase in CXCL8 expression has been observed in human umbilical vein endothelial cells (HUVECs) [203], human pulmonary microvascular endothelial cells and human pulmonary aortic endothelial cells [204]. This effect depends on the activation of the p38 MAPK and PI3K $\rightarrow$ PKB/Akt pathway, which in turn activates AP-1, HIF-1 and NF- $\mathrm{kB}$ [204]. The activation of HIF-2 also plays a significant role in this process [205].

In human microvascular endothelial HMEC-1 cells, hypoxia reduces CXCL8 expression (Figure 3) $[206,207]$ in a process mediated by HIF-1 and HIF-, which regulate the expression of CXCL8 [208]. HIF-1 increases the expression of Bach1, which in turn reduces the expression of erythroid 2-related factor (Nrf2) [207]. This reduces the expression of CXCL8. HIF-1 also decreases the expression of c-Myc. HIF-2 has the opposite effect as it increases the expression of c-Myc [208]. HIF-2 also stabilizes the c-Myc:Max complex which increases c-Myc action, unlike HIF- 1 which destabilizes the complex. As c-Myc increases the expression of CXCL8 by binding to the CXCL8 promoter, both HIFs can indirectly alter the expression of CXCL8, with a more pronounced influence of HIF-1.

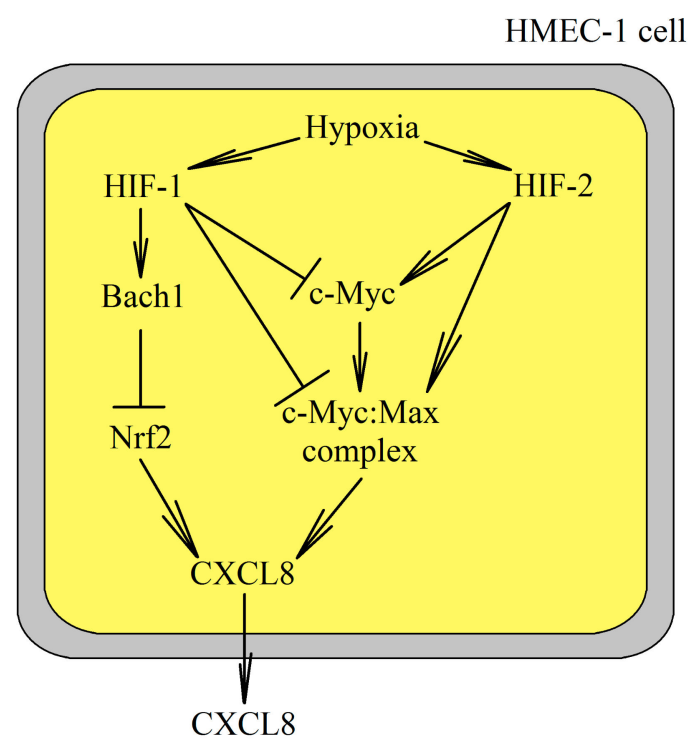

Figure 3. The mechanism of interaction between HIF-1 and HIF-2 in the change of CXCL8 expression in HMEC-1 cells. HIF-1 reduces CXCL8 expression in HMEC-1 cells due to an increase in Bach1 expression, which reduces erythroid 2-related factor (Nrf2) activation. HIF-1 also reduces the expression of c-Myc and destabilizes the c-Myc:Max complex. HIF-2 increases the expression of CXCL8 in these cells, which is related to an increase in c-Myc expression and stabilization of the c-Myc:Max complex.

Cycling hypoxia alone does not increase the expression of CXCL8 and does not affect the activation of NF- $\mathrm{kB}$, as shown in HUVECs [47]. Nevertheless, this type of hypoxia does increase the response of these cells to proinflammatory factors such as tumor necrosis factor $\alpha(\mathrm{TNF}-\alpha)$. This results in a more intense activation of NF- $\mathrm{KB}$ and expression of CXCL8 and ICAM-1 in HUVECs than would occur as a result of TNF- $\alpha$ alone, which in turn increases 
the adhesion of these cells to the walls of blood vessels and thus their recruitment into the tumor niche.

\subsection{Influence of Hypoxia on CXCR1 and CXCR2 Expression}

CXCR2 is a receptor of the CXCL1, CXCL2, CXCL3, CXCL5, CXCL6, CXCL7 and CXCL8 chemokines, and CXCR1 is receptor of CXCL6 and CXCL8 [6,79,81]. Changes in the expression of these receptors affect the action of these chemokines. Chronic hypoxia increases the expression of CXCR1 and CXCR2 in cervical carcinoma cells [209] and prostate cancer cells [210]. This effect is dependent on HIF-1 and NF-KB activation [210]. Chronic hypoxia also increases the expression of CXCR2 on aortic endothelial cells [211]. This may indicate the effect of hypoxia on angiogenesis by increasing the sensitivity of endothelial cells to CXCR2 ligands. However, this effect is dependent on the type of tumor-for example, chronic hypoxia reduces the expression of CXCR2 in gastric cancer cells [212].

There are no data on the influence of cycling hypoxia on the expression of the described receptors on cancer cells. Screening studies did not show any influence on three cell lines: PC-3 (prostate cancer cells), SK-OV-3 (ovarian adenocarcinoma cells) and WM793B (melanoma cells) [14]. However, cycling hypoxia increases NF- $\mathrm{kB}$-dependent expression of CXCR2 in neutrophil cells [197] but decreases CXCR1 expression [213]. Increasing the expression of CXCR2 increases the effect of CXCL1, CXCL2 and CXCL8 chemokines on these cells. In particular, there is a decrease in spontaneous apoptosis of these cells which supports TAN accumulation in the tumor niche $[196,197]$.

\section{Ligands of Receptor CXCR3}

\subsection{The Influence of Hypoxia on CXCL4 Expression}

Chronic hypoxia increases the expression of CXCL4 in MUM2B uveal melanoma cells [214]. This effect is mediated by HIF-1 [214] and dependent on the type of tumor. For example, chronic hypoxia does not change the expression of CXCL4 in lung adenocarcinoma cells [154].

\subsection{Effects of Hypoxia on CXCL9 Expression}

Chronic hypoxia does not affect the expression of CXCL9 in cervical cancer cells [167] and lung adenocarcinoma cells [154]. Nevertheless, chronic hypoxia increases the expression of this chemokine in primary rat brain astrocytes [165] and hepatocarcinoma cells [157].

\subsection{Effects of Hypoxia on the Expression of CXCL10}

The CXCL10 gene promoter contains one binding site for HIF and four binding sites for NF-KB [215]. For this reason, the overexpression of HIF-2 increases the expression of CXCL10 in murine articular chondrocytes [163]. Chronic hypoxia also increases the expression of CXCL10 in HepG2 cells (hepatocellular carcinoma) [216]. On the other hand, studies on cancer cells such as HeLa cells (cervical cancer) [156], 9L glioma cells (brain tumor) [217], breast cancer cells [175,177], ovarian cancer cells, colon cancer cells and lung cancer cells [175] show that chronic hypoxia reduces the expression of CXCL10, as in studies on noncancer cells such as primary hepatocytes [178] and rabbit alveolar macrophages [201]. This effect may depend on HIF-1 or on the reduction in transcriptional NF-kB activity [218]. However, in some types of cancer cells, such as acute myeloid leukaemia cells [155], chronic hypoxia does not change the expression of CXCL10.

There are also four binding sites for NF-kB in the CXCL10 gene promoter [215]. For this reason, by activating NF- $\mathrm{KB}$ and without the involvement of HIF, chronic hypoxia increases CXCL10 expression in cardiac microvascular endothelial cells [215]. In the same way, cycling hypoxia increases the expression of CXCL10 in M1 polarized macrophages [202], although not in M2 macrophages [202]. 


\subsection{Effect of Hypoxia on CXCL11 Expression}

The influence of chronic hypoxia on the expression of CXCL11 depends on the research model. In HeLa cervical cancer cells [169] and primary human monocytes [164], chronic hypoxia reduces the expression of this chemokine. In cervical cancer, C33a cells increase [167]. However, chronic hypoxia does not affect the expression of CXCL11 in hepatocarcinoma cells [157].

\subsection{Effects of Hypoxia on CXCR3 Expression}

$\mathrm{CoCl}_{2}$ increases CXCR3 receptor expression in the model of renal cell carcinoma 786-O cells [219]. $\mathrm{CoCl}_{2}$ is a substance that mimics the effects of hypoxia [220]. For this reason, it can be assumed that chronic hypoxia increases the expression of CXCR3 on cancer cells.

\section{Effect of Hypoxia on the Expression and Function of CXCL12 and CXCR4 and CXCR7 Receptors}

\subsection{Effect of Hypoxia on CXCL12 Expression}

Chronic hypoxia affects the expression of CXCL12. However, this effect depends on the adopted research model. In WM793B melanoma cells [14] and GOT1 cells (ileal carcinoids) [221], chronic hypoxia reduces CXCL12 expression. Chronic hypoxia also reduces the expression of CXCL12 in MDSCs [222], which is related to the HIF-1-dependent increase in the level of miRNA-210. Chronic hypoxia does not affect the expression of CXC12 in breast cancer cells [166], gastric cancer cells [212], lung adenocarcinoma cells [154], rhabdomyosarcoma cells [183] and uveal melanoma cells [179]. However, it does increase the expression of CXC12 in cervical cancer cells [167], clear cell-renal cell carcinomas cells [223], glioblastoma multiforme cells [224-226], multiple myeloma plasma cells [227], ovarian carcinomas cells [228] and endothelial cells [229,230]. This effect is dependent on HIF-1 $[212,223,224,227,231]$ and HIF-2 [158,227]. Transforming growth factor $\beta$ (TGF- $\beta$ ) may also participate in the mechanism of increasing CXCL12 expression [224,232]. On the other hand, in HUVECs, the increase in CXCL12 expression is dependent on NF$\mathrm{KB}$ p65, which increases the expression of long intergenic nonprotein coding RNA 1693 (LINC01693), which functions as a miRNA-302d sponge [230]. miRNA-302d reduces the expression of CXCL12-i.e., hypoxia increases the expression of this chemokine via NF-KB.

Cycling hypoxia, akin to chronic hypoxia, reduces the expression of CXCL12 in WM793B melanoma cells [14].

\subsection{Effect of Hypoxia on the Expression of CXCL12 Receptors: CXCR4 and CXCR7}

Chronic hypoxia increases the expression of CXCR4 in tumor cells such as breast cancer cells (Figure 4) [233-238], chondrosarcoma cells [239,240], clear cell-renal cell carcinomas cells [223], chronic lymphocytic leukemia [241], colon cancer cells [62,242,243], gastric cancer cells [212,244], glioblastoma multiforme cells [226,245-247], GOT1 cells (ileal carcinoids) [221], lung cancer cells [248,249], melanoma cells [250,251], multiple myeloma cells [252], oral squamous cell carcinoma cells [253], osteosarcoma cells [254,255], pancreatic ductal adenocarcinoma cells [256,257], renal cell carcinoma cells [258], and retinoblastoma cells [259]. However, chronic hypoxia does not universally induce CXCR4 expression in tumor cells-for example, in hepatocellular carcinoma cells it only increases the expression of CXCR4 in some cell lines [260].

The expression of CXCR7 under the influence of chronic hypoxia is upregulated in glioblastoma multiforme cells [261]. However, its expression is not altered by chronic hypoxia in acute myeloid leukemia cells [262] and breast cancer cells [237,243].

Cycling hypoxia, unlike chronic hypoxia, does not affect CXCR4 expression in PC-3 prostate cancer cells and SK-OV-3 ovarian adenocarcinoma cells [14]. However, cycling hypoxia increases CXCR7 expression in PC-3 prostate cancer cells, although this effect is not as intense as in chronic hypoxia [14]. In contrast to chronic hypoxia, cycling hypoxia does not affect the expression of CXCR7 in SK-OV-3 ovarian adenocarcinoma cells [14]. 

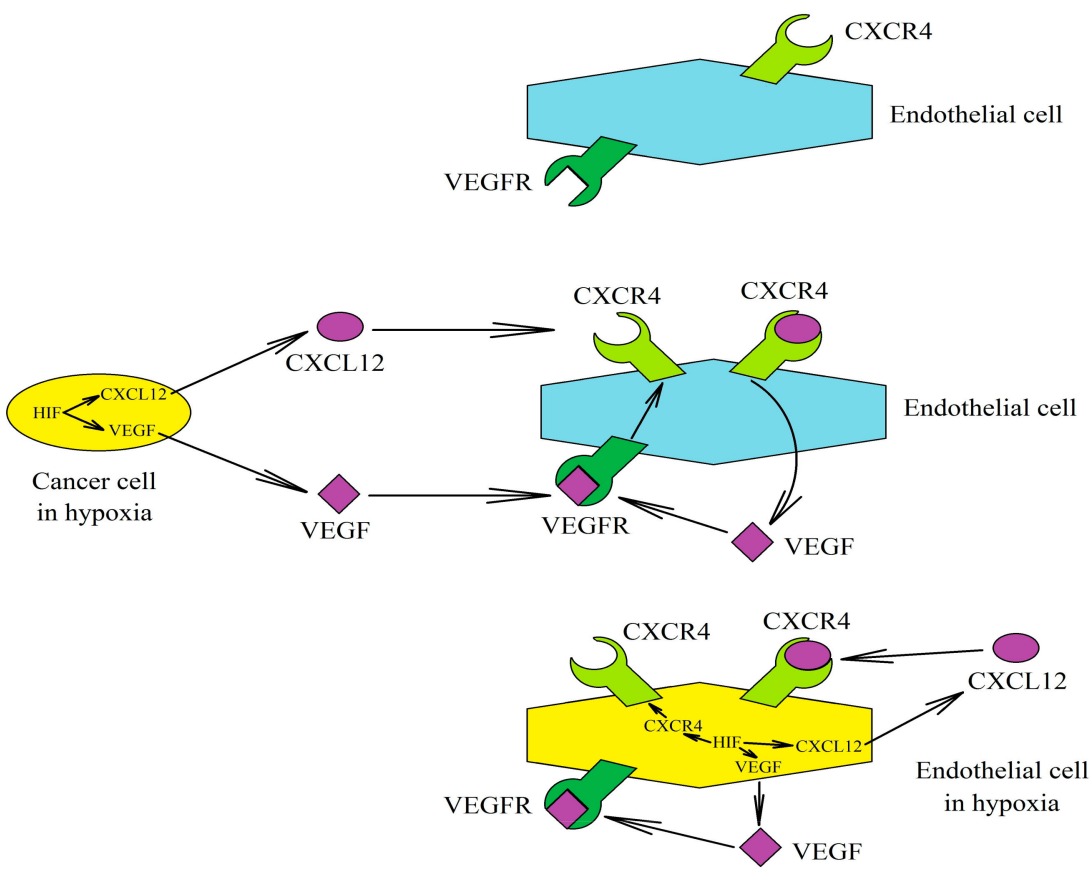

Figure 4. Association between the CXCL12 $\rightarrow$ CXCR4 axis and vascular endothelial growth factor (VEGF) in angiogenesis induced by chronic hypoxia. Chronic hypoxia increases the expression of VEGF and CXCL12 in a cancer cell, factors that act on endothelial cells. VEGF increases the expression of CXCR4 and thus enhances the sensitivity of these cells to CXCL12. In turn, CXCL12 causes an increase in VEGF expression in endothelial cells. In addition, chronic hypoxia itself can act directly on endothelial cells. It increases the expression of CXCR4, CXCL12 and VEGF, which act in an autocrine manner on these cells. As a result of the described factors, angiogenesis occurs.

Expression of CXCR4 is increased directly by HIF-1 [62,159,212,223,229,239,241,244, $248,252-255,258,263,264]$ and HIF-2 [159,161,229,248,265], because the promoter of the CXCR4 gene contains HRE $[263,266]$. In particular, chronic hypoxia by HIF-2 increases the expression of CXCR4 in macrophages [161] and endothelial progenitor cells [267]. In breast cancer cells, chronic hypoxia increases CXCR4 expression independently of HIF-1, depending only on NF- $\mathrm{KB}$ [233]. Chronic hypoxia increases the expression of CXCR4 in the pancreatic ductal adenocarcinoma cell line by reducing the level of miRNA-150 [257]. In chondrosarcoma, chronic hypoxia increases the expression of miRNA-181a, which controls the expression of the regulator of G-protein signaling 16 (RGS16) [240,268]. This protein reduces the expression of CXCR4. As such, miRNA-181a increases the expression of CXCR4. In breast cancer cells $\mathrm{CoCl}_{2}$ (chemical hypoxia-mimicking agent) reduces miRNA-302a expression [238]. This miRNA regulates the expression of CXCR4-therefore, reducing the level of miRNA-302a increases the expression of CXCR4.

Hypoxia may also alter the level of CXCR4 expression in leukemias. In multiple myeloma cells, chronic hypoxia increases CXCR4 expression in a process dependent on HIF-1 [252]. However, hypoxia can interfere with the action of CXCL12 on these cells by HIF-2-dependent upregulation of CC motif chemokine receptor 1 (CCR1) [269]. Activation of this receptor reduces the action of CXCL12 on multiple myeloma cells. In leukemic monocytic cells, mild and severe chronic hypoxias reduce the expression of CXCR4 [270]. This is related to a HIF-1- and HIF-2-dependent increase in the level of miRNA-146a, which reduces the expression of CXCR4 in these cells. Chronic hypoxia also causes a decreased migration of leukemic cells in response to CXCL12. This is related to the disturbance of $\mathrm{Akt} / \mathrm{PKB}$ activation as shown by experiments on the HL-60 promyelocytic leukemia cell line [234]. In acute myeloid leukemia, the dysfunction of CXCL12 by chronic hypoxia is dependent on cholesterol depletion, which interferes with the function of lipid rafts and thus the internalization of CXCR4 [271]. In contrast, in myeloma cell lines U266 and 
RPMI8226, chronic hypoxia increases the expression of CXCR4 by increasing the expression of miRNA-210 [272].

\subsection{Consequences of Hypoxia's Influence on the CXCL12 $\rightarrow$ CXCR4 Axis}

Hypoxia acts on the CXCL12 $\rightarrow$ CXCR4 axis. However, the ramifications of this effect are too complex to be outlined in the section on tumor function of CXC chemokines. For this reason, consequences of the action of hypoxia on this axis are described in this part of the review.

The CXCL12 $\rightarrow$ CXCR4 pathway induced by chronic hypoxia has a significant procancer effect, especially due to the angiogenic influence of CXCL12 [98]. In a tumor cell, chronic hypoxia increases the expression of VEGF and in some types of tumor cells it increases the expression of CXCL12 [228]. CXCL12 causes an increase in VEGF expression on endothelial cells [100]. VEGF increases expression of CXCR4 on HUVECs [99] and human brain microvascular endothelial cells [245]—sensitizing these cells to angiogenic CXCL12 [229]. Hypoxia also acts directly on endothelial cells by increasing the expression of VEGF [273] and CXCR4; the latter is shown by studies on HUVECs [230,259,263,274] and microvascular endothelial cells [250]. To a lesser extent, chronic hypoxia also increases the expression of CXCR4 on microvascular endothelial cells [250] and CXCL12 in HUVECs $[229,230]$. Importantly, it should be remembered that chronic hypoxia does not only result in angiogenesis by inducing the expression of CXCL12 and VEGF, but via other factors as well.

At the same time, a chronic hypoxia-induced increase in CXCR4 expression stimulates the proliferation of cancer cells $[256,275]$ and causes their migration and invasion $[244,246,248,249,255-257,275]$, especially in combination with the chronic hypoxiainduced increase in CXCL12 expression in tumor cells $[167,223,228]$. The upregulation of CXCR4 also aids in the transendothelial migration of cancer cells [229], which is followed by the invasion of cancer cells to neighboring tissues and organs [253,276-278]. In breast cancer, the CXCL12 $\rightarrow$ CXCR4 axis also participates in another stage of metastasis. After reaching the bone, breast cancer cells are retained close to osteoprogenitor cells in the hypoxic niche [279]; the elevated expression of CXCL12 in the latter promotes the growth of breast cancer cells and thereby results in bone metastasis.

In many types of cancer cells, chronic hypoxia does not increase the expression of CXCL12 [154,166,179,183,212], although with an increased expression of CXCR4, the sensitivity of tumor cells to CXCL12 increases. In addition, cancer cell migration involving the CXCL12 $\rightarrow$ CXCR4 axis may be caused by other cells-for example, CAFs in gastric cancer, where chronic hypoxia increases the expression of CXCL12 and thus acts on tumor cells with a hypoxia-enhanced expression of CXCR4 [212].

Chronic hypoxia also increases the expression of CXCR4 in monocytes [164,263] and macrophages $[159,263]$. For this reason, it can cause the accumulation of TAMs and MDSCs at sites with a high expression of CXCL12 [122], particularly in tumors [122,223,224,228]. A similar mechanism is postulated for the accumulation of $T_{\text {regs }}$ in the hypoxic niche [136], and the recruitment of neural stem cells in glioblastoma multiforme [225] and CD34 ${ }^{+}$ endothelial progenitor cells in pituitary adenomas [280].

Chronic hypoxia increases the expression of CXCR4 on multiple myelomas in a HIF1-dependent manner [252]. This leads to the migration of these cells and their homing to bone marrow via the CXCL12 $\rightarrow$ CXCR4 pathway [281]. Bones require physiological hypoxia for normal hematopoiesis [282,283], but are also involved in multiple myeloma. In this cancer, hypoxia increases the expression of angiogenic factors such as VEGF, CXCL8 and CXCL12 [283,284]. The upregulation of CXCL12 is induced by HIF-2 and to a lesser extent by HIF-1 [227], resulting in angiogenesis and osteoclastic bone resorption [227]. This, in turn, leads to angiogenesis and interference with the normal bone marrow microenvironment. Hypoxia in bone marrow can also cause the egress of multiple myeloma cells [269], as HIF-2 increases the expression of CCR1. Activation of this receptor by CC 
motif chemokine ligand 3 (CCL3) reduces the response of multiple myelomas to CXCL12 and the consequent egress of these cells from bone marrow.

CXCR4 also has a function inside the tumor cell. Its activation by CXCL12 triggers its entry and internalization into the nucleus, where it interacts with HIF-1, enhancing the expression of genes dependent on this transcription factor [285].

\section{Influence of Hypoxia on the CXCL13 $\rightarrow$ CXCR5 Axis}

Chronic hypoxia does not alter CXCL13 expression in breast cancer cells [166], hepatocarcinoma cells [157] and lung adenocarcinoma cells [154]. Although the promoter of the CXCL13 gene contains HRE [162], no data are available on the direct chronic hypoxiainduced upregulation of CXCL13 in a tumor cell. It is only known that chronic hypoxia increases the expression of CXCL13 in adipocytes [286]. On the other hand, chronic hypoxia may affect the expression of CXCL13 in the tumor indirectly-for example, via an increased expression of TGF- $\beta$ in myofibroblasts in prostate tumors [287].

There are no reports of hypoxia affecting the expression of CXCR5 (CXCL13 receptor) in cancer cells. Nevertheless, the promoter of the CXCR5 gene contains HRE [286]. For this reason, chronic hypoxia increases the expression of CXCR5 as demonstrated in experiments on adipocytes [286].

\section{Effect of Hypoxia on CXCL14 Expression}

Since the promoter of the CXCL14 gene contains HRE [288], chronic hypoxia can increase the expression of CXCL14, for example, in cervical cancer cells [169]. The overexpression of HIF-2 $\alpha$ in murine articular chondrocytes also increases the expression of CXCL14 [163]. Nevertheless, chronic hypoxia does not change the expression of the described chemokine in lung adenocarcinoma cells [154].

\section{Effect of Hypoxia on CXCL15 Expression}

CXCL15 is a murine chemokine that is not found in humans and for this reason has been poorly researched. CXCL15 is mainly expressed in murine lungs [289], and to a much lesser extent in the murine digestive tract and urogenital organs [80]. The expression of this chemokine can be increased by chronic hypoxia, as shown by experiments on murine articular chondrocytes, where the overexpression of HIF- $2 \alpha$ resulted in an elevated expression of CXCL15 [163].

\section{Influence of Hypoxia on the CXCL16 $\rightarrow$ CXCR6 Axis}

The effect of chronic hypoxia on the expression of CXCL16 depends on the type of cancer. In hepatocarcinoma cells [157] and HUVECs [105], chronic hypoxia increases the expression of CXCL16. In HUVECs, this effect is dependent on HIF-1 [105]. In breast cancer cells, chronic hypoxia also increases the expression of CXCL16, although this is dependent on the CXCL10-CXCL16 loop [290]. In contrast, chronic hypoxia does not alter CXCL16 expression in lung adenocarcinoma cells [154]. Finally, it increases the expression of the CXCL16 receptor (CXCR6) in breast cancer cells in a HIF-1-dependent manner [290,291].

\section{Influence of Hypoxia on the CXCL17 $\rightarrow$ CXCR8 Axis}

There are no data available on the effect of hypoxia on the expression of CXCL17, or its receptor (CXCR8), in tumor cells. However, experiments on myocytes have shown that chronic hypoxia increases the expression of CXCR8 in a HIF-1-dependent process [292,293]. This indicates that hypoxia increases the expression of this receptor on cancer cells and thus enhances the effect of CXCL17 on these cells.

CXCL17 is a ligand of CXCR8 [294], although there is currently a discussion on the existence of another, yet undiscovered, receptor $[295,296]$. A potential discovery of a new receptor could reveal new methods of regulating the action of CXCL17, including the influence of hypoxia on the action of this chemokine. 


\section{Cancer Therapy}

\subsection{Cancer Therapy Targeting Hypoxia}

Hypoxia and the signaling pathways activated by hypoxia are convenient therapeutic targets in cancer therapy (Figure 5). This is related to the fact that hypoxia occurs mainly in the tumor. For this reason, research focuses on inhibitors of the transcriptional activities of HIF-1 and HIF-2 [297]. On the other hand, oxygen concentration may be increased in the tumor and thus hypoxia may be prevented by using hyperbaric oxygen therapy $[298,299]$. However, as hypoxia is also important in the functioning of hematopoietic stem cells under physiological conditions [300-302], any therapy against hypoxia may also cause side effects which affect the production of various blood cells.

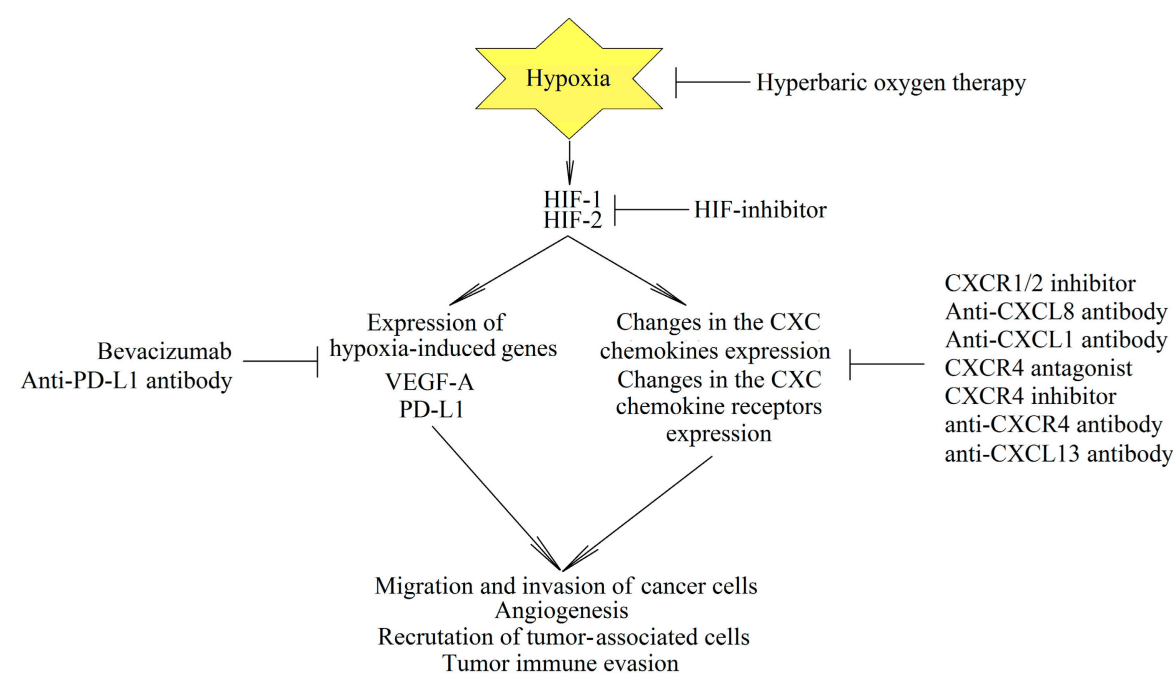

Figure 5. Hypoxia as an essential element of cancer mechanisms and as a therapeutic target. Hypoxia leads to an increase in the expression of genes essential for tumor progression, especially CXC chemokines, CXC chemokine receptors, and other genes encoding VEGF-A and programmed deathligand 1 (PD-L1). As hypoxia occurs mainly in the tumor, cancer-specific therapy can be developed by using hyperbaric oxygen therapy and HIF inhibitors. Researchers are also investigating the potential of inactivating specific proteins whose expression is increased by hypoxia.

In another therapeutic approach, anticancer therapy targets certain proteins induced by hypoxia. A monoclonal anti-VEGF-A antibody known as bevacizumab is already used in therapy as an angiostatic factor [303,304]. Inactivation of PD-L1 is also being studied as a way to increase the effectiveness of anticancer immunotherapy $[305,306]$. However, targeting CXC chemokines remains a very important issue in cancer therapy, especially as hypoxia alters the expression of these chemoattractant cytokines, which promotes the growth of tumors.

\subsection{Cancer Therapy Targeting CXC Chemokines}

Changes in the expression of CXC chemokines under the influence of hypoxia are an important element of cancer processes. For this reason, CXC chemokines and their receptors are a convenient therapeutic target in the treatment of cancer, with most clinical and preclinical studies focusing on CXCR2 and CXCR4 receptors and their ligands.

The chemokines which act through CXCR1 and CXCR2 participate in numerous cancer processes [7], and therefore CXCR1 / 2 inhibitors [307-309] as well as CXCR2 inhibitors [310], are considered as potential anticancer drugs. They reduce the proliferation and migration of cancer cells and inhibit angiogenesis, and their combination with current anticancer drugs has shown promising results [307]. Anti-CXCL8 antibody [311,312], CXCL8 small interfering RNA [313], and anti-CXCL1 antibody [314] have also been tested and such therapies have shown a reduction in tumor cell migration and angiogenesis. Another 
therapeutic approach involves the transduction of CXCR2 to antitumor lymphocytes which accumulate in the tumor niche and exhibit anticancer activity there $[315,316]$.

Drugs targeting the CXCL12 $\rightarrow$ CXCR4 axis have also been investigated. Although the use of anti-CXCR4 antibodies are being tested in anticancer monotherapy [317], better results are obtained when drugs targeting this axis are combined with those already used in anticancer therapy. This approach involves CXCR4 antagonists, CXCR4 inhibitors, anti-CXCR4 antibodies and CXCR7 inhibitors [318-322]. One of the advantages of these drugs is their ability to decrease drug resistance-e.g., to tamoxifen by CXCR4 antagonists in breast cancer [323]. They also have the potential to increase the effectiveness of immunotherapy [324,325]. An anti-CXCR4 antibody, or peptides recognizing CXCR4, have also been tested to target cytotoxic substances against cancer stem cells in acute myelogenous leukemia [326], breast cancer cells [327], colorectal cancer cells [328] and multiple myeloma [329]. This method can also be used to retarget an adenovirus vector against a tumor cell in gene therapy [330].

Another direction of research is the use of gene therapy to increase the expression of chemokines that induce the infiltration of a tumor by anticancer TILs-for example, CXCR3 ligands such as CXCL10 [331-333] and CXCL11 [334]. Promising results are also shown in the combination of current therapeutic methods, e.g., radiotherapy, with gene therapy which increases the expression of CXCL10 [335]. However, CXCL10 induces tamoxifen resistance in breast cancer [336] and therefore any interference with the expression of the aforementioned chemokine during therapy should be performed after careful examination of its interaction with other anticancer drugs.

Drugs that interfere with the action of other CXC chemokine receptors are also being tested, although these studies are not as advanced. An example of this is drugs which block the CXCL13 $\rightarrow$ CXCR5 axis, with in vitro studies on breast cancer cells showing that anti-CXCL13 antibodies induce tumor cell apoptosis [337]. However, to date, no advanced animal model studies or clinical trials have been conducted in this area.

Another promising chemokine is CXCL16, which causes tumor infiltration by anticancer TILs [153]. The expression and release of this chemokine in a tumor cell is increased by ionizing radiation [338], and so combining radiotherapy (increasing the expression of chemokines that result in the recruitment of anticancer lymphocytes) with immunotherapy (which consists of introducing modified anticancer lymphocytes into the patient's body) has been postulated.

Author Contributions: J.K.: writing-original draft preparation; K.K.: investigation; P.K. (Patrycja Kupnicka): investigation; P.K. (Patrycja Kapczuk): investigation; B.G.-S.: investigation; I.G.: investigation; D.C.: funding acquisition; I.B.-B.: writing-review and editing. All authors have read and agreed to the published version of the manuscript.

Funding: This study was supported by the statutory budget of the Department of Biochemistry and Medical Chemistry Pomeranian Medical University in Szczecin, Poland.

Institutional Review Board Statement: Not applicable.

Informed Consent Statement: Not applicable.

Data Availability Statement: Not applicable.

Conflicts of Interest: The authors declare no conflict of interest.

\section{References}

1. Bray, F.; Ferlay, J.; Soerjomataram, I.; Siegel, R.L.; Torre, L.A.; Jemal, A. Global cancer statistics 2018: GLOBOCAN estimates of incidence and mortality worldwide for 36 cancers in 185 countries. CA Cancer J. Clin. 2018, 68, 394-424. [CrossRef]

2. GBD 2017 Causes of Death Collaborators. Global, regional, and national age-sex-specific mortality for 282 causes of death in 195 countries and territories, 1980-2017: A systematic analysis for the Global Burden of Disease Study 2017. Lancet 2018, 392, 1736-1788. [CrossRef]

3. Wang, M.; Zhao, J.; Zhang, L.; Wei, F.; Lian, Y.; Wu, Y.; Gong, Z.; Zhang, S.; Zhou, J.; Cao, K.; et al. Role of tumor microenvironment in tumorigenesis. J. Cancer 2017, 8, 761-773. [CrossRef] 
4. Mu, X.; Shi, W.; Xu, Y.; Xu, C.; Zhao, T.; Geng, B.; Yang, J.; Pan, J.; Hu, S.; Zhang, C.; et al. Tumor-derived lactate induces M2 macrophage polarization via the activation of the ERK/STAT3 signaling pathway in breast cancer. Cell Cycle 2018, 17, 428-438. [CrossRef] [PubMed]

5. Lian, G.; Chen, S.; Ouyang, M.; Li, F.; Chen, L.; Yang, J. Colon Cancer Cell Secretes EGF to Promote M2 Polarization of TAM through EGFR/PI3K/AKT/mTOR Pathway. Technol. Cancer Res. Treat. 2019, 18. [CrossRef] [PubMed]

6. Hughes, C.E.; Nibbs, R.J.B. A guide to chemokines and their receptors. FEBS J. 2018, 285, 2944-2971. [CrossRef] [PubMed]

7. Do, H.T.T.; Lee, C.H.; Cho, J. Chemokines and their Receptors: Multifaceted Roles in Cancer Progression and Potential Value as Cancer Prognostic Markers. Cancers 2020, 12, 287. [CrossRef]

8. Span, P.N.; Bussink, J. Biology of hypoxia. Semin. Nucl. Med. 2015, 45, 101-109. [CrossRef]

9. Cárdenas-Navia, L.I.; Mace, D.; Richardson, R.A.; Wilson, D.F.; Shan, S.; Dewhirst, M.W. The pervasive presence of fluctuating oxygenation in tumors. Cancer Res. 2008, 68, 5812-5819. [CrossRef]

10. Baluk, P.; Morikawa, S.; Haskell, A.; Mancuso, M.; McDonald, D.M. Abnormalities of basement membrane on blood vessels and endothelial sprouts in tumors. Am. J. Pathol. 2003, 163, 1801-1815. [CrossRef]

11. Lanzen, J.; Braun, R.D.; Klitzman, B.; Brizel, D.; Secomb, T.W.; Dewhirst, M.W. Direct demonstration of instabilities in oxygen concentrations within the extravascular compartment of an experimental tumor. Cancer Res. 2006, 66, 2219-2223. [CrossRef] [PubMed]

12. Panek, R.; Welsh, L.; Baker, L.; Schmidt, M.A.; Wong, K.H.; Riddell, A.M.; Koh, D.M.; Dunlop, A.; Mcquaid, D.; d'Arcy, J.A.; et al. Noninvasive Imaging of Cycling Hypoxia in Head and Neck Cancer Using Intrinsic Susceptibility MRI. Clin. Cancer Res. 2017, 23, 4233-4241. [CrossRef] [PubMed]

13. Ellingsen, C.; Ovrebø, K.M.; Galappathi, K.; Mathiesen, B.; Rofstad, E.K. $\mathrm{pO}_{2}$ fluctuation pattern and cycling hypoxia in human cervical carcinoma and melanoma xenografts. Int. J. Radiat. Oncol. Biol. Phys. 2012, 83, 1317-1323. [CrossRef] [PubMed]

14. Olbryt, M.; Habryka, A.; Student, S.; Jarząb, M.; Tyszkiewicz, T.; Lisowska, K.M. Global gene expression profiling in three tumor cell lines subjected to experimental cycling and chronic hypoxia. PLoS ONE 2014, 9, e105104.

15. Hirsilä, M.; Koivunen, P.; Günzler, V.; Kivirikko, K.I.; Myllyharju, J. Characterization of the human prolyl 4-hydroxylases that modify the hypoxia-inducible factor. J. Biol. Chem. 2003, 278, 30772-30780. [CrossRef]

16. Hsieh, C.H.; Lee, C.H.; Liang, J.A.; Yu, C.Y.; Shyu, W.C. Cycling hypoxia increases U87 glioma cell radioresistance via ROS induced higher and long-term HIF-1 signal transduction activity. Oncol. Rep. 2010, 24, 1629-1636. [CrossRef]

17. Chen, W.L.; Wang, C.C.; Lin, Y.J.; Wu, C.P.; Hsieh, C.H. Cycling hypoxia induces chemoresistance through the activation of reactive oxygen species-mediated B-cell lymphoma extra-long pathway in glioblastoma multiforme. J. Transl. Med. 2015, 13, 389. [CrossRef]

18. Maxwell, P.H.; Wiesener, M.S.; Chang, G.W.; Clifford, S.C.; Vaux, E.C.; Cockman, M.E.; Wykoff, C.C.; Pugh, C.W.; Maher, E.R.; Ratcliffe, P.J. The tumour suppressor protein VHL targets hypoxia-inducible factors for oxygen-dependent proteolysis. Nature 1999, 399, 271-275. [CrossRef]

19. Hon, W.C.; Wilson, M.I.; Harlos, K.; Claridge, T.D.; Schofield, C.J.; Pugh, C.W.; Maxwell, P.H.; Ratcliffe, P.J.; Stuart, D.I.; Jones, E.Y. Structural basis for the recognition of hydroxyproline in HIF-1 alpha by pVHL. Nature 2002, 417, 975-978. [CrossRef]

20. Ke, Q.; Costa, M. Hypoxia-inducible factor-1 (HIF-1). Mol. Pharmacol. 2006, 70, 1469-1480. [CrossRef]

21. Masson, N.; Willam, C.; Maxwell, P.H.; Pugh, C.W.; Ratcliffe, P.J. Independent function of two destruction domains in hypoxiainducible factor-alpha chains activated by prolyl hydroxylation. EMBO J. 2001, 20, 5197-5206. [CrossRef] [PubMed]

22. Guan, Z.; Ding, C.; Du, Y.; Zhang, K.; Zhu, J.N.; Zhang, T.; He, D.; Xu, S.; Wang, X.; Fan, J. HAF drives the switch of HIF-1 $\alpha$ to HIF- $2 \alpha$ by activating the NF-KB pathway, leading to malignant behavior of T24 bladder cancer cells. Int. J. Oncol. 2014, 44, 393-402. [CrossRef] [PubMed]

23. D'Angelo, G.; Duplan, E.; Boyer, N.; Vigne, P.; Frelin, C. Hypoxia up-regulates prolyl hydroxylase activity: A feedback mechanism that limits HIF-1 responses during reoxygenation. J. Biol. Chem. 2003, 278, 38183-38187. [CrossRef]

24. Stiehl, D.P.; Wirthner, R.; Köditz, J.; Spielmann, P.; Camenisch, G.; Wenger, R.H. Increased prolyl 4-hydroxylase domain proteins compensate for decreased oxygen levels. Evidence for an autoregulatory oxygen-sensing system. J. Biol. Chem. 2006, 281, 23482-23491. [CrossRef] [PubMed]

25. Ginouvès, A.; Ilc, K.; Macías, N.; Pouysségur, J.; Berra, E. PHDs overactivation during chronic hypoxia "desensitizes" HIFalpha and protects cells from necrosis. Proc. Natl. Acad. Sci. USA 2008, 105, 4745-4750. [CrossRef]

26. Fujita, N.; Markova, D.; Anderson, D.G.; Chiba, K.; Toyama, Y.; Shapiro, I.M.; Risbud, M.V. Expression of prolyl hydroxylases (PHDs) is selectively controlled by HIF-1 and HIF-2 proteins in nucleus pulposus cells of the intervertebral disc: Distinct roles of PHD2 and PHD3 proteins in controlling HIF-1 $\alpha$ activity in hypoxia. J. Biol. Chem. 2012, 287, 16975-16986. [CrossRef]

27. Gerald, D.; Berra, E.; Frapart, Y.M.; Chan, D.A.; Giaccia, A.J.; Mansuy, D.; Pouysségur, J.; Yaniv, M.; Mechta-Grigoriou, F. JunD reduces tumor angiogenesis by protecting cells from oxidative stress. Cell 2004, 118, 781-794. [CrossRef]

28. Toffoli, S.; Feron, O.; Raes, M.; Michiels, C. Intermittent hypoxia changes HIF-1alpha phosphorylation pattern in endothelial cells: Unravelling of a new PKA-dependent regulation of HIF-1alpha. Biochim. Biophys. Acta 2007, 1773, 1558-1571. [CrossRef]

29. Zhang, Y.L.; Tavakoli, H.; Chachisvilis, M. Apparent PKA activity responds to intermittent hypoxia in bone cells: A redox pathway? Am. J. Physiol. Heart Circ. Physiol. 2010, 299, H225-H235. [CrossRef]

30. Yuan, G.; Nanduri, J.; Khan, S.; Semenza, G.L.; Prabhakar, N.R. Induction of HIF-1alpha expression by intermittent hypoxia: Involvement of NADPH oxidase, Ca2+ signaling, prolyl hydroxylases, and mTOR. J. Cell Physiol. 2008, 217, 674-685. [CrossRef] 
31. Malec, V.; Gottschald, O.R.; Li, S.; Rose, F.; Seeger, W.; Hänze, J. HIF-1 alpha signaling is augmented during intermittent hypoxia by induction of the Nrf2 pathway in NOX1-expressing adenocarcinoma A549 cells. Free Radic. Biol. Med. 2010, 48, 1626-1635. [CrossRef] [PubMed]

32. Masson, N.; Singleton, R.S.; Sekirnik, R.; Trudgian, D.C.; Ambrose, L.J.; Miranda, M.X.; Tian, Y.M.; Kessler, B.M.; Schofield, C.J.; Ratcliffe, P.J. The FIH hydroxylase is a cellular peroxide sensor that modulates HIF transcriptional activity. EMBO Rep. 2012, 13, 251-257. [CrossRef] [PubMed]

33. Freedman, S.J.; Sun, Z.Y.; Poy, F.; Kung, A.L.; Livingston, D.M.; Wagner, G.; Eck, M.J. Structural basis for recruitment of CBP/p300 by hypoxia-inducible factor-1 alpha. Proc. Natl. Acad. Sci. USA 2002, 99, 5367-5372. [CrossRef]

34. Lando, D.; Peet, D.J.; Whelan, D.A.; Gorman, J.J.; Whitelaw, M.L. Asparagine hydroxylation of the HIF transactivation domain a hypoxic switch. Science 2002, 295, 858-861. [CrossRef]

35. Koivunen, P.; Hirsilä, M.; Günzler, V.; Kivirikko, K.I.; Myllyharju, J. Catalytic properties of the asparaginyl hydroxylase (FIH) in the oxygen sensing pathway are distinct from those of its prolyl 4-hydroxylases. J. Biol. Chem. 2004, 279, 9899-9904. [CrossRef]

36. Tuckerman, J.R.; Zhao, Y.; Hewitson, K.S.; Tian, Y.M.; Pugh, C.W.; Ratcliffe, P.J.; Mole, D.R. Determination and comparison of specific activity of the HIF-prolyl hydroxylases. FEBS Lett. 2004, 576, 145-150. [CrossRef]

37. Cummins, E.P.; Berra, E.; Comerford, K.M.; Ginouves, A.; Fitzgerald, K.T.; Seeballuck, F.; Godson, C.; Nielsen, J.E.; Moynagh, P.; Pouyssegur, J.; et al. Prolyl hydroxylase-1 negatively regulates IkappaB kinase-beta, giving insight into hypoxia-induced NFkappaB activity. Proc. Natl. Acad. Sci. USA 2006, 103, 18154-18159. [CrossRef]

38. Wang, L.; Niu, Z.; Wang, X.; Li, Z.; Liu, Y.; Luo, F.; Yan, X. PHD2 exerts anti-cancer and anti-inflammatory effects in colon cancer xenografts mice via attenuating NF-kB activity. Life Sci. 2020, 242, 117167. [CrossRef]

39. Culver, C.; Sundqvist, A.; Mudie, S.; Melvin, A.; Xirodimas, D.; Rocha, S. Mechanism of hypoxia-induced NF-kappaB. Mol. Cell Biol. 2010, 30, 4901-4921. [CrossRef]

40. Quintero, M.; Gonzalez-Martin, M.D.C.; Vega-Agapito, V.; Gonzalez, C.; Obeso, A.; Farré, R.; Agapito, T.; Yubero, S. The effects of intermittent hypoxia on redox status, NF- $\mathrm{KB}$ activation, and plasma lipid levels are dependent on the lowest oxygen saturation. Free Radic. Biol. Med. 2013, 65, 1143-1154. [CrossRef]

41. Gutsche, K.; Randi, E.B.; Blank, V.; Fink, D.; Wenger, R.H.; Leo, C.; Scholz, C.C. Intermittent hypoxia confers pro-metastatic gene expression selectively through NF-kB in inflammatory breast cancer cells. Free Radic. Biol. Med. 2016, 101, 129-142. [CrossRef]

42. Belaiba, R.S.; Bonello, S.; Zähringer, C.; Schmidt, S.; Hess, J.; Kietzmann, T.; Görlach, A. Hypoxia up-regulates hypoxia-inducible factor-1alpha transcription by involving phosphatidylinositol 3-kinase and nuclear factor kappaB in pulmonary artery smooth muscle cells. Mol. Biol. Cell 2007, 18, 4691-4697. [CrossRef]

43. Jiang, Y.; Zhu, Y.; Wang, X.; Gong, J.; Hu, C.; Guo, B.; Zhu, B.; Li, Y. Temporal regulation of HIF-1 and NF-kB in hypoxic hepatocarcinoma cells. Oncotarget 2015, 6, 9409-9419. [CrossRef]

44. Shin, D.H.; Li, S.H.; Yang, S.W.; Lee, B.L.; Lee, M.K.; Park, J.W. Inhibitor of nuclear factor-kappaB alpha derepresses hypoxiainducible factor-1 during moderate hypoxia by sequestering factor inhibiting hypoxia-inducible factor from hypoxia-inducible factor 1alpha. FEBS J. 2009, 276, 3470-3480. [CrossRef]

45. Mendonça, D.B.; Mendonça, G.; Aragão, F.J.; Cooper, L.F. NF-kB suppresses HIF-1 $\alpha$ response by competing for P300 binding. Biochem. Biophys. Res. Commun. 2011, 404, 997-1003. [CrossRef]

46. Ravenna, L.; Principessa, L.; Verdina, A.; Salvatori, L.; Russo, M.A.; Petrangeli, E. Distinct phenotypes of human prostate cancer cells associate with different adaptation to hypoxia and pro-inflammatory gene expression. PLoS ONE 2014, 9, e96250.

47. Tellier, C.; Desmet, D.; Petit, L.; Finet, L.; Graux, C.; Raes, M.; Feron, O.; Michiels, C. Cycling hypoxia induces a specific amplified inflammatory phenotype in endothelial cells and enhances tumor-promoting inflammation in vivo. Neoplasia 2015, 17, 66-78. [CrossRef]

48. Song, D.; Fang, G.; Mao, S.Z.; Ye, X.; Liu, G.; Miller, E.J.; Greenberg, H.; Liu, S.F. Selective inhibition of endothelial NF-кB signaling attenuates chronic intermittent hypoxia-induced atherosclerosis in mice. Atherosclerosis 2018, 270, 68-75. [CrossRef]

49. Graeber, T.G.; Osmanian, C.; Jacks, T.; Housman, D.E.; Koch, C.J.; Lowe, S.W.; Giaccia, A.J. Hypoxia-mediated selection of cells with diminished apoptotic potential in solid tumours. Nature 1996, 379, 88-91. [CrossRef]

50. Soeda, A.; Park, M.; Lee, D.; Mintz, A.; Androutsellis-Theotokis, A.; McKay, R.D.; Engh, J.; Iwama, T.; Kunisada, T.; Kassam, A.B.; et al. Hypoxia promotes expansion of the CD133-positive glioma stem cells through activation of HIF-1alpha. Oncogene 2009, 28, 3949-3959. [CrossRef]

51. Seo, E.J.; Kim, D.K.; Jang, I.H.; Choi, E.J.; Shin, S.H.; Lee, S.I.; Kwon, S.M.; Kim, K.H.; Suh, D.S.; Kim, J.H. Hypoxia-NOTCH1-SOX2 signaling is important for maintaining cancer stem cells in ovarian cancer. Oncotarget 2016, 7, 55624-55638. [CrossRef] [PubMed]

52. Zhang, C.; Samanta, D.; Lu, H.; Bullen, J.W.; Zhang, H.; Chen, I.; He, X.; Semenza, G.L. Hypoxia induces the breast cancer stem cell phenotype by HIF-dependent and ALKBH5-mediated $\mathrm{m}^{6} \mathrm{~A}-$ demethylation of NANOG mRNA. Proc. Natl. Acad. Sci. USA 2016, 113, E2047-E2056. [CrossRef] [PubMed]

53. Qin, J.; Liu, Y.; Lu, Y.; Liu, M.; Li, M.; Li, J.; Wu, L. Hypoxia-inducible factor 1 alpha promotes cancer stem cells-like properties in human ovarian cancer cells by upregulating SIRT1 expression. Sci. Rep. 2017, 7, 10592. [CrossRef] [PubMed]

54. Mahkamova, K.; Latar, N.; Aspinall, S.; Meeson, A. Hypoxia Increases Thyroid Cancer Stem Cell-Enriched Side Population. World J. Surg. 2018, 42, 350-357. [CrossRef] [PubMed]

55. Bhuria, V.; Xing, J.; Scholta, T.; Bui, K.C.; Nguyen, M.L.T.; Malek, N.P.; Bozko, P.; Plentz, R.R. Hypoxia induced Sonic Hedgehog signaling regulates cancer stemness, epithelial-to-mesenchymal transition and invasion in cholangiocarcinoma. Exp. Cell Res. 2019, 385, 111671. [CrossRef] 
56. Matsuoka, J.; Yashiro, M.; Doi, Y.; Fuyuhiro, Y.; Kato, Y.; Shinto, O.; Noda, S.; Kashiwagi, S.; Aomatsu, N.; Hirakawa, T.; et al. Hypoxia stimulates the EMT of gastric cancer cells through autocrine TGF $\beta$ signaling. PLoS ONE 2013, 8, e62310. [CrossRef] [PubMed]

57. Zuo, J.; Wen, J.; Lei, M.; Wen, M.; Li, S.; Lv, X.; Luo, Z.; Wen, G. Hypoxia promotes the invasion and metastasis of laryngeal cancer cells via EMT. Med. Oncol. 2016, 33, 15. [CrossRef]

58. Wang, X.H.; He, X.; Jin, H.Y.; Liang, J.X.; Li, N. Effect of hypoxia on the Twist1 in EMT of cervical cancer cells. Eur. Rev Med. Pharmacol. Sci. 2018, 22, 6633-6639.

59. Tang, C.; Liu, T.; Wang, K.; Wang, X.; Xu, S.; He, D.; Zeng, J. Transcriptional regulation of FoxM1 by HIF-1 $\alpha$ mediates hypoxiainduced EMT in prostate cancer. Oncol. Rep. 2019, 42, 1307-1318. [CrossRef]

60. Terashima, J.; Sampei, S.; Iidzuka, M.; Ohsakama, A.; Tachikawa, C.; Satoh, J.; Kudo, K.; Habano, W.; Ozawa, S. VEGF expression is regulated by HIF-1 $\alpha$ and ARNT in 3D KYSE-70, esophageal cancer cell spheroids. Cell Biol. Int. 2016, 40, 1187-1194. [CrossRef]

61. Cesário, J.M.; Brito, R.B.; Malta, C.S.; Silva, C.S.; Matos, Y.S.; Kunz, T.C.; Urbano, J.J.; Oliveira, L.V.; Dalboni, M.A.; Dellê, H. A simple method to induce hypoxia-induced vascular endothelial growth factor-A (VEGF-A) expression in T24 human bladder cancer cells. In Vitro Cell Dev. Biol. Anim. 2017, 53, 272-276. [CrossRef] [PubMed]

62. Zong, S.; Li, W.; Li, H.; Han, S.; Liu, S.; Shi, Q.; Hou, F. Identification of hypoxia-regulated angiogenic genes in colorectal cancer. Biochem. Biophys. Res. Commun. 2017, 493, 461-467. [CrossRef] [PubMed]

63. Ke, X.; Chen, C.; Song, Y.; Cai, Q.; Li, J.; Tang, Y.; Han, X.; Qu, W.; Chen, A.; Wang, H.; et al. Hypoxia modifies the polarization of macrophages and their inflammatory microenvironment, and inhibits malignant behavior in cancer cells. Oncol. Lett. 2019, 18, 5871-5878. [CrossRef] [PubMed]

64. Balsamo, M.; Manzini, C.; Pietra, G.; Raggi, F.; Blengio, F.; Mingari, M.C.; Varesio, L.; Moretta, L.; Bosco, M.C.; Vitale, M. Hypoxia downregulates the expression of activating receptors involved in NK-cell-mediated target cell killing without affecting ADCC. Eur. J. Immunol. 2013, 43, 2756-2764. [CrossRef] [PubMed]

65. Chen, C.H.; Li, S.X.; Xiang, L.X.; Mu, H.Q.; Wang, S.B.; Yu, K.Y. HIF-1 $\alpha$ induces immune escape of prostate cancer by regulating NCR1/NKp46 signaling through miR-224. Biochem. Biophys. Res. Commun. 2018, 503, 228-234. [CrossRef]

66. Li, Y.; Patel, S.P.; Roszik, J.; Qin, Y. Hypoxia-Driven Immunosuppressive Metabolites in the Tumor Microenvironment: New Approaches for Combinational Immunotherapy. Front. Immunol. 2018, 9, 1591. [CrossRef]

67. Song, X.; Zhang, Y.; Zhang, L.; Song, W.; Shi, L. Hypoxia enhances indoleamine 2,3-dioxygenase production in dendritic cells. Oncotarget 2018, 9, 11572-11580. [CrossRef]

68. Pérez-Tomás, R.; Pérez-Guillén, I. Lactate in the Tumor Microenvironment: An Essential Molecule in Cancer Progression and Treatment. Cancers 2020, 12, 3244. [CrossRef]

69. Miller, F.; Kentsis, A.; Osman, R.; Pan, Z.Q. Inactivation of VHL by tumorigenic mutations that disrupt dynamic coupling of the pVHL.hypoxia-inducible transcription factor-1alpha complex. J. Biol. Chem. 2005, 280, 7985-7996. [CrossRef]

70. Gossage, L.; Eisen, T. Alterations in VHL as potential biomarkers in renal-cell carcinoma. Nat. Rev. Clin. Oncol. 2010, 7, 277-288. [CrossRef]

71. Wang, E.; Zhang, C.; Polavaram, N.; Liu, F.; Wu, G.; Schroeder, M.A.; Lau, J.S.; Mukhopadhyay, D.; Jiang, S.W.; O’Neill, B.P.; et al. The role of factor inhibiting HIF (FIH-1) in inhibiting HIF-1 transcriptional activity in glioblastoma multiforme. PLoS ONE 2014, 9, e86102. [CrossRef] [PubMed]

72. Bullen, J.W.; Tchernyshyov, I.; Holewinski, R.J.; DeVine, L.; Wu, F.; Venkatraman, V.; Kass, D.L.; Cole, R.N.; Van Eyk, J.; Semenza, G.L. Protein kinase A-dependent phosphorylation stimulates the transcriptional activity of hypoxia-inducible factor 1 . Sci. Signal. 2016, 9, ra56. [CrossRef] [PubMed]

73. Stiehl, D.P.; Jelkmann, W.; Wenger, R.H.; Hellwig-Bürgel, T. Normoxic induction of the hypoxia-inducible factor 1alpha by insulin and interleukin-1beta involves the phosphatidylinositol 3-kinase pathway. FEBS Lett. 2002, 512, 157-162. [CrossRef]

74. Treins, C.; Giorgetti-Peraldi, S.; Murdaca, J.; Semenza, G.L.; Van Obberghen, E. Insulin stimulates hypoxia-inducible factor 1 through a phosphatidylinositol 3-kinase/target of rapamycin-dependent signaling pathway. J. Biol. Chem. 2002, 277, 27975-27981. [CrossRef] [PubMed]

75. Frede, S.; Stockmann, C.; Freitag, P.; Fandrey, J. Bacterial lipopolysaccharide induces HIF-1 activation in human monocytes via p44/42 MAPK and NF-kappaB. Biochem. J. 2006, 396, 517-527. [CrossRef]

76. Mylonis, I.; Chachami, G.; Samiotaki, M.; Panayotou, G.; Paraskeva, E.; Kalousi, A.; Georgatsou, E.; Bonanou, S.; Simos, G. Identification of MAPK phosphorylation sites and their role in the localization and activity of hypoxia-inducible factor-1alpha. $J$. Biol. Chem. 2006, 281, 33095-33106. [CrossRef]

77. Koyasu, S.; Kobayashi, M.; Goto, Y.; Hiraoka, M.; Harada, H. Regulatory mechanisms of hypoxia-inducible factor 1 activity: Two decades of knowledge. Cancer Sci. 2018, 109, 560-571. [CrossRef]

78. Lim, J.H.; Lee, Y.M.; Chun, Y.S.; Chen, J.; Kim, J.E.; Park, J.W. Sirtuin 1 modulates cellular responses to hypoxia by deacetylating hypoxia-inducible factor 1alpha. Mol. Cell 2010, 38, 864-878. [CrossRef]

79. Zlotnik, A.; Yoshie, O. Chemokines: A new classification system and their role in immunity. Immunity 2000, 12, 121-127. [CrossRef]

80. Schmitz, J.M.; McCracken, V.J.; Dimmitt, R.A.; Lorenz, R.G. Expression of CXCL15 (Lungkine) in murine gastrointestinal, urogenital, and endocrine organs. J. HistoChem. Cytochem. 2007, 55, 515-524. [CrossRef]

81. Wuyts, A.; Proost, P.; Lenaerts, J.P.; Ben-Baruch, A.; Van Damme, J.; Wang, J.M. Differential usage of the CXC chemokine receptors 1 and 2 by interleukin-8, granulocyte chemotactic protein-2 and epithelial-cell-derived neutrophil attractant-78. Eur. J. Biochem. 1998, 255, 67-73. [CrossRef] [PubMed] 
82. Jenh, C.H.; Cox, M.A.; Hipkin, W.; Lu, T.; Pugliese-Sivo, C.; Gonsiorek, W.; Chou, C.C.; Narula, S.K.; Zavodny, P.J. Human B cellattracting chemokine 1 (BCA-1; CXCL13) is an agonist for the human CXCR3 receptor. Cytokine 2001, 15, 113-121. [CrossRef] [PubMed]

83. Burns, J.M.; Summers, B.C.; Wang, Y.; Melikian, A.; Berahovich, R.; Miao, Z.; Penfold, M.E.; Sunshine, M.J.; Littman, D.R.; Kuo, C.J.; et al. A novel chemokine receptor for SDF-1 and I-TAC involved in cell survival, cell adhesion, and tumor development. J. Exp. Med. 2006, 203, 2201-2213. [CrossRef] [PubMed]

84. Hattermann, K.; Bartsch, K.; Gebhardt, H.H.; Mehdorn, H.M.; Synowitz, M.; Schmitt, A.D.; Mentlein, R.; Held-Feindt, J. “Inverse signaling" of the transmembrane chemokine CXCL16 contributes to proliferative and anti-apoptotic effects in cultured human meningioma cells. Cell Commun. Signal. 2016, 14, 26. [CrossRef] [PubMed]

85. Tanegashima, K.; Suzuki, K.; Nakayama, Y.; Tsuji, K.; Shigenaga, A.; Otaka, A.; Hara, T. CXCL14 is a natural inhibitor of the CXCL12-CXCR4 signaling axis. FEBS Lett. 2013, 587, 1731-1735. [CrossRef]

86. Otte, M.; Kliewer, A.; Schütz, D.; Reimann, C.; Schulz, S.; Stumm, R. CXCL14 is no direct modulator of CXCR4. FEBS Lett. 2014, 588, 4769-4775. [CrossRef]

87. Wang, Y.; Weng, X.; Wang, L.; Hao, M.; Li, Y.; Hou, L.; Liang, Y.; Wu, T.; Yao, M.; Lin, G.; et al. HIC1 deletion promotes breast cancer progression by activating tumor cell/fibroblast crosstalk. J. Clin. Investig. 2018, 128, 5235-5250. [CrossRef]

88. Tanegashima, K.; Takahashi, R.; Nuriya, H.; Iwase, R.; Naruse, N.; Tsuji, K.; Shigenaga, A.; Otaka, A.; Hara, T. CXCL14 Acts as a Specific Carrier of CpG DNA into Dendritic Cells and Activates Toll-like Receptor 9-mediated Adaptive Immunity. EBioMedicine 2017, 24, 247-256. [CrossRef]

89. Cheng, C.L.; Yang, S.C.; Lai, C.Y.; Wang, C.K.; Chang, C.F.; Lin, C.Y.; Chen, W.J.; Lin, P.Y.; Wu, H.C.; Ma, N.; et al. CXCL14 Maintains hESC Self-Renewal through Binding to IGF-1R and Activation of the IGF-1R Pathway. Cells 2020, 9, 1706. [CrossRef]

90. Strieter, R.M.; Polverini, P.J.; Kunkel, S.L.; Arenberg, D.A.; Burdick, M.D.; Kasper, J.; Dzuiba, J.; Van Damme, J.; Walz, A.; Marriott, D.; et al. The functional role of the ELR motif in CXC chemokine-mediated angiogenesis. J. Biol. Chem. 1995, 270, 27348-27357. [CrossRef]

91. Salcedo, R.; Resau, J.H.; Halverson, D.; Hudson, E.A.; Dambach, M.; Powell, D.; Wasserman, K.; Oppenheim, J.J. Differential expression and responsiveness of chemokine receptors (CXCR1-3) by human microvascular endothelial cells and umbilical vein endothelial cells. FASEB J. 2000, 14, 2055-2064. [CrossRef] [PubMed]

92. Heidemann, J.; Ogawa, H.; Dwinell, M.B.; Rafiee, P.; Maaser, C.; Gockel, H.R.; Otterson, M.F.; Ota, D.M.; Lugering, N.; Domschke, W.; et al. Angiogenic effects of interleukin 8 (CXCL8) in human intestinal microvascular endothelial cells are mediated by CXCR2. J. Biol. Chem. 2003, 278, 8508-8515. [CrossRef] [PubMed]

93. Nör, J.E.; Christensen, J.; Liu, J.; Peters, M.; Mooney, D.J.; Strieter, R.M.; Polverini, P.J. Up-Regulation of Bcl-2 in microvascular endothelial cells enhances intratumoral angiogenesis and accelerates tumor growth. Cancer Res. 2001, 61, $2183-2188$.

94. Warner, K.A.; Miyazawa, M.; Cordeiro, M.M.; Love, W.J.; Pinsky, M.S.; Neiva, K.G.; Spalding, A.C.; Nör, J.E. Endothelial cells enhance tumor cell invasion through a crosstalk mediated by CXC chemokine signaling. Neoplasia 2008, 10, 131-139. [CrossRef] [PubMed]

95. Romagnani, P.; Annunziato, F.; Lasagni, L.; Lazzeri, E.; Beltrame, C.; Francalanci, M.; Uguccioni, M.; Galli, G.; Cosmi, L.; Maurenzig, L.; et al. Cell cycle-dependent expression of CXC chemokine receptor 3 by endothelial cells mediates angiostatic activity. J. Clin. Investig. 2001, 107, 53-63. [CrossRef]

96. Parsonage, G.; Machado, L.R.; Hui, J.W.; McLarnon, A.; Schmaler, T.; Balasothy, M.; To, K.F.; Vlantis, A.C.; van Hasselt, C.A.; Lo, K.W.; et al. CXCR6 and CCR5 localize T lymphocyte subsets in nasopharyngeal carcinoma. Am. J. Pathol. 2012, 180, 1215-1222. [CrossRef]

97. Yang, J.; Richmond, A. The angiostatic activity of interferon-inducible protein-10/CXCL10 in human melanoma depends on binding to CXCR3 but not to glycosaminoglycan. Mol. Ther. 2004, 9, 846-855. [CrossRef]

98. Van Raemdonck, K.; Gouwy, M.; Lepers, S.A.; Van Damme, J.; Struyf, S. CXCL4L1 and CXCL4 signaling in human lymphatic and microvascular endothelial cells and activated lymphocytes: Involvement of mitogen-activated protein (MAP) kinases, Src and p70S6 kinase. Angiogenesis 2014, 17, 631-640. [CrossRef]

99. Mirshahi, F.; Pourtau, J.; Li, H.; Muraine, M.; Trochon, V.; Legrand, E.; Vannier, J.; Soria, J.; Vasse, M.; Soria, C. SDF-1 activity on microvascular endothelial cells: Consequences on angiogenesis in in vitro and in vivo models. Thromb. Res. 2000, 99, 587-594. [CrossRef]

100. Salcedo, R.; Wasserman, K.; Young, H.A.; Grimm, M.C.; Howard, O.M.; Anver, M.R.; Kleinman, H.K.; Murphy, W.J.; Oppenheim, J.J. Vascular endothelial growth factor and basic fibroblast growth factor induce expression of CXCR4 on human endothelial cells: In vivo neovascularization induced by stromal-derived factor-1alpha. Am. J. Pathol. 1999, 154, 1125-1135. [CrossRef]

101. Neuhaus, T.; Stier, S.; Totzke, G.; Gruenewald, E.; Fronhoffs, S.; Sachinidis, A.; Vetter, H.; Ko, Y.D. Stromal cell-derived factor 1alpha (SDF-1alpha) induces gene-expression of early growth response-1 (Egr-1) and VEGF in human arterial endothelial cells and enhances VEGF induced cell proliferation. Cell Prolif. 2003, 36, 75-86. [CrossRef] [PubMed]

102. Li, M.; Lu, Y.; Xu, Y.; Wang, J.; Zhang, C.; Du, Y.; Wang, L.; Li, L.; Wang, B.; Shen, J.; et al. Horizontal transfer of exosomal CXCR4 promotes murine hepatocarcinoma cell migration, invasion and lymphangiogenesis. Gene 2018, 676, 101-109. [CrossRef] [PubMed]

103. Spinetti, G.; Camarda, G.; Bernardini, G.; Romano Di Peppe, S.; Capogrossi, M.C.; Napolitano, M. The chemokine CXCL13 (BCA-1) inhibits FGF-2 effects on endothelial cells. Biochem. Biophys. Res. Commun. 2001, 289, 19-24. [CrossRef] [PubMed]

104. Shellenberger, T.D.; Wang, M.; Gujrati, M.; Jayakumar, A.; Strieter, R.M.; Burdick, M.D.; Ioannides, C.G.; Efferson, C.L.; El-Naggar, A.K.; Roberts, D.; et al. BRAK/CXCL14 is a potent inhibitor of angiogenesis and a chemotactic factor for immature dendritic cells. Cancer Res. 2004, 64, 8262-8270. [CrossRef]

105. Liu, Y.; Chang, Q.; Wu, X.; Yu, Y.; Zhang, H. Effect of chemokine CXCL14 on in vitro angiogenesis of human hepatocellular carcinoma cells. Arch. Physiol. Biochem. 2020. [CrossRef] 
106. Yu, X.; Zhao, R.; Lin, S.; Bai, X.; Zhang, L.; Yuan, S.; Sun, L. CXCL16 induces angiogenesis in autocrine signaling pathway involving hypoxia-inducible factor $1 \alpha$ in human umbilical vein endothelial cells. Oncol. Rep. 2016, 35, 1557-1565. [CrossRef]

107. Lee, W.Y.; Wang, C.J.; Lin, T.Y.; Hsiao, C.L.; Luo, C.W. CXCL17, an orphan chemokine, acts as a novel angiogenic and antiinflammatory factor. Am. J. Physiol. Endocrinol. Metab. 2013, 304, E32-E40. [CrossRef]

108. Fan, L.; Zhu, Q.; Liu, L.; Zhu, C.; Huang, H.; Lu, S.; Liu, P. CXCL13 is androgen-responsive and involved in androgen induced prostate cancer cell migration and invasion. Oncotarget 2017, 8, 53244-53261. [CrossRef]

109. Guo, Y.J.; Zhou, Y.J.; Yang, X.L.; Shao, Z.M.; Ou, Z.L. The role and clinical significance of the CXCL17-CXCR8 (GPR35) axis in breast cancer. Biochem. Biophys. Res. Commun. 2017, 493, 1159-1167. [CrossRef]

110. Hong, L.; Wang, S.; Li, W.; Wu, D.; Chen, W. Tumor-associated macrophages promote the metastasis of ovarian carcinoma cells by enhancing CXCL16/CXCR6 expression. Pathol. Res. Pract. 2018, 214, 1345-1351. [CrossRef]

111. Li, Y.; Reader, J.C.; Ma, X.; Kundu, N.; Kochel, T.; Fulton, A.M. Divergent roles of CXCR3 isoforms in promoting cancer stem-like cell survival and metastasis. Breast Cancer Res. Treat. 2015, 149, 403-415. [CrossRef] [PubMed]

112. Reynders, N.; Abboud, D.; Baragli, A.; Noman, M.Z.; Rogister, B.; Niclou, S.P.; Heveker, N.; Janji, B.; Hanson, J.; Szpakowska, M.; et al. The Distinct Roles of CXCR3 Variants and Their Ligands in the Tumor Microenvironment. Cells 2019, 8, 613. [CrossRef] [PubMed]

113. Lin, K.; Zou, R.; Lin, F.; Zheng, S.; Shen, X.; Xue, X. Expression and effect of CXCL14 in colorectal carcinoma. Mol. Med. Rep. 2014, 10, 1561-1568. [CrossRef] [PubMed]

114. Li, X.; Zhao, L.; Meng, T. Upregulated CXCL14 is associated with poor survival outcomes and promotes ovarian cancer cells proliferation. Cell Biochem. Funct. 2020, 38, 613-620. [CrossRef]

115. Moser, B.; Schumacher, C.; von Tscharner, V.; Clark-Lewis, I.; Baggiolini, M. Neutrophil-activating peptide 2 and gro/melanoma growth-stimulatory activity interact with neutrophil-activating peptide 1 /interleukin 8 receptors on human neutrophils. J. Biol. Chem. 1991, 266, 10666-10671. [CrossRef]

116. Haqqani, A.S.; Sandhu, J.K.; Birnboim, H.C. Expression of interleukin-8 promotes neutrophil infiltration and genetic instability in mutatect tumors. Neoplasia 2000, 2, 561-568. [CrossRef]

117. Jablonska, J.; Wu, C.F.; Andzinski, L.; Leschner, S.; Weiss, S. CXCR2-mediated tumor-associated neutrophil recruitment is regulated by IFN- $\beta$. Int. J. Cancer 2014, 134, 1346-1358. [CrossRef]

118. Gijsbers, K.; Gouwy, M.; Struyf, S.; Wuyts, A.; Proost, P.; Opdenakker, G.; Penninckx, F.; Ectors, N.; Geboes, K.; Van Damme, J. GCP-2/CXCL6 synergizes with other endothelial cell-derived chemokines in neutrophil mobilization and is associated with angiogenesis in gastrointestinal tumors. Exp. Cell Res. 2005, 303, 331-342. [CrossRef]

119. Chao, T.; Furth, E.E.; Vonderheide, R.H. CXCR2-Dependent Accumulation of Tumor-Associated Neutrophils Regulates T-cell Immunity in Pancreatic Ductal Adenocarcinoma. Cancer Immunol. Res. 2016, 4, 968-982. [CrossRef]

120. Ligocki, A.J.; Niederkorn, J.Y. Natural Killer T Cells Contribute to Neutrophil Recruitment and Ocular Tissue Damage in a Model of Intraocular Tumor Rejection. Investig. Ophthalmol. Vis. Sci. 2016, 57, 813-823. [CrossRef]

121. Yuan, M.; Zhu, H.; Xu, J.; Zheng, Y.; Cao, X.; Liu, Q. Tumor-Derived CXCL1 Promotes Lung Cancer Growth via Recruitment of Tumor-Associated Neutrophils. J. Immunol. Res. 2016, 2016, 6530410. [CrossRef] [PubMed]

122. Tulotta, C.; Stefanescu, C.; Chen, Q.; Torraca, V.; Meijer, A.H.; Snaar-Jagalska, B.E. CXCR4 signaling regulates metastatic onset by controlling neutrophil motility and response to malignant cells. Sci. Rep. 2019, 9, 2399. [CrossRef] [PubMed]

123. Wang, S.C.; Hong, J.H.; Hsueh, C.; Chiang, C.S. Tumor-secreted SDF-1 promotes glioma invasiveness and TAM tropism toward hypoxia in a murine astrocytoma model. Lab. Investig. 2012, 92, 151-162. [CrossRef] [PubMed]

124. Oka, T.; Sugaya, M.; Takahashi, N.; Takahashi, T.; Shibata, S.; Miyagaki, T.; Asano, Y.; Sato, S. CXCL17 Attenuates ImiquimodInduced Psoriasis-like Skin Inflammation by Recruiting Myeloid-Derived Suppressor Cells and Regulatory T Cells. J. Immunol. 2017, 198, 3897-3908. [CrossRef] [PubMed]

125. Shi, H.; Han, X.; Sun, Y.; Shang, C.; Wei, M.; Ba, X.; Zeng, X. Chemokine (C-X-C motif) ligand 1 and CXCL2 produced by tumor promote the generation of monocytic myeloid-derived suppressor cells. Cancer Sci. 2018, 109, 3826-3839. [CrossRef]

126. Taki, M.; Abiko, K.; Baba, T.; Hamanishi, J.; Yamaguchi, K.; Murakami, R.; Yamanoi, K.; Horikawa, N.; Hosoe, Y.; Nakamura, E.; et al. Snail promotes ovarian cancer progression by recruiting myeloid-derived suppressor cells via CXCR2 ligand upregulation. Nat. Commun. 2018, 9, 1685. [CrossRef]

127. Li, B.H.; Garstka, M.A.; Li, Z.F. Chemokines and their receptors promoting the recruitment of myeloid-derived suppressor cells into the tumor. Mol. Immunol. 2020, 117, 201-215. [CrossRef]

128. Takahashi, R.; Amano, H.; Ito, Y.; Eshima, K.; Satoh, T.; Iwamura, M.; Nakamura, M.; Kitasato, H.; Uematsu, S.; Raouf, J.; et al. Microsomal prostaglandin E synthase-1 promotes lung metastasis via SDF-1/CXCR4-mediated recruitment of CD11b+Gr1+MDSCs from bone marrow. Biomed. Pharmacother. 2020, 121, 109581. [CrossRef]

129. Unver, N.; Esendagli, G.; Yilmaz, G.; Guc, D. CXCL7-induced macrophage infiltration in lung tumor is independent of CXCR2 expression: CXCL7-induced macrophage chemotaxis in LLC tumors. Cytokine 2015, 75, 330-337. [CrossRef]

130. Krawczyk, K.M.; Nilsson, H.; Allaoui, R.; Lindgren, D.; Arvidsson, M.; Leandersson, K.; Johansson, M.E. Papillary renal cell carcinoma-derived chemerin, IL-8, and CXCL16 promote monocyte recruitment and differentiation into foam-cell macrophages. Lab. Investig. 2017, 97, 1296-1305. [CrossRef]

131. Zhang, R.; Qi, F.; Zhao, F.; Li, G.; Shao, S.; Zhang, X.; Yuan, L.; Feng, Y. Cancer-associated fibroblasts enhance tumor-associated macrophages enrichment and suppress NK cells function in colorectal cancer. Cell Death Dis. 2019, 10, 273. [CrossRef] [PubMed] 
132. Xu, F.; Shi, J.; Yu, B.; Ni, W.; Wu, X.; Gu, Z. Chemokines mediate mesenchymal stem cell migration toward gliomas in vitro. Oncol. Rep. 2010, 23, 1561-1567. [CrossRef] [PubMed]

133. Jung, Y.; Kim, J.K.; Shiozawa, Y.; Wang, J.; Mishra, A.; Joseph, J.; Berry, J.E.; McGee, S.; Lee, E.; Sun, H.; et al. Recruitment of mesenchymal stem cells into prostate tumours promotes metastasis. Nat. Commun. 2013, 4, 1795. [CrossRef] [PubMed]

134. Kasashima, H.; Yashiro, M.; Nakamae, H.; Kitayama, K.; Masuda, G.; Kinoshita, H.; Fukuoka, T.; Hasegawa, T.; Nakane, T.; Hino, M.; et al. CXCL1-Chemokine (C-X-C Motif) Receptor 2 Signaling Stimulates the Recruitment of Bone Marrow-Derived Mesenchymal Cells into Diffuse-Type Gastric Cancer Stroma. Am. J. Pathol. 2016, 186, 3028-3039. [CrossRef]

135. Zheng, X.B.; He, X.W.; Zhang, L.J.; Qin, H.B.; Lin, X.T.; Liu, X.H.; Zhou, C.; Liu, H.S.; Hu, T.; Cheng, H.C.; et al. Bone marrowderived CXCR4-overexpressing MSCs display increased homing to intestine and ameliorate colitis-associated tumorigenesis in mice. Gastroenterol. Rep. 2019, 7, 127-138. [CrossRef]

136. Meng, L.; Zhao, Y.; Bu, W.; Li, X.; Liu, X.; Zhou, D.; Chen, Y.; Zheng, S.; Lin, Q.; Liu, Q.; et al. Bone mesenchymal stem cells are recruited via CXCL8-CXCR2 and promote EMT through TGF- $\beta$ signal pathways in oral squamous carcinoma. Cell Prolif. 2020, 53, e12859. [CrossRef]

137. Yan, M.; Jene, N.; Byrne, D.; Millar, E.K.; O’Toole, S.A.; McNeil, C.M.; Bates, G.J.; Harris, A.L.; Banham, A.H.; Sutherland, R.L.; et al. Recruitment of regulatory $\mathrm{T}$ cells is correlated with hypoxia-induced CXCR4 expression, and is associated with poor prognosis in basal-like breast cancers. Breast Cancer Res. 2011, 13, R47. [CrossRef]

138. Yang, S.; Wang, B.; Guan, C.; Wu, B.; Cai, C.; Wang, M.; Zhang, B.; Liu, T.; Yang, P. Foxp3+IL-17+ T cells promote development of cancer-initiating cells in colorectal cancer. J. Leukoc. Biol. 2011, 89, 85-91. [CrossRef]

139. Redjimi, N.; Raffin, C.; Raimbaud, I.; Pignon, P.; Matsuzaki, J.; Odunsi, K.; Valmori, D.; Ayyoub, M. CXCR3+ T regulatory cells selectively accumulate in human ovarian carcinomas to limit type I immunity. Cancer Res. 2012, 72, 4351-4360. [CrossRef]

140. Ye, J.; Ma, C.; Wang, F.; Hsueh, E.C.; Toth, K.; Huang, Y.; Mo, W.; Liu, S.; Han, B.; Varvares, M.A.; et al. Specific recruitment of $\gamma \delta$ regulatory $\mathrm{T}$ cells in human breast cancer. Cancer Res. 2013, 73, 6137-6148. [CrossRef]

141. Lv, M.; Xu, Y.; Tang, R.; Ren, J.; Shen, S.; Chen, Y.; Liu, B.; Hou, Y.; Wang, T. miR141-CXCL1-CXCR2 signaling-induced Treg recruitment regulates metastases and survival of non-small cell lung cancer. Mol. Cancer Ther. 2014, 13, 3152-3162. [CrossRef] [PubMed]

142. Li, C.X.; Ling, C.C.; Shao, Y.; Xu, A.; Li, X.C.; Ng, K.T.; Liu, X.B.; Ma, Y.Y.; Qi, X.; Liu, H.; et al. CXCL10/CXCR3 signaling mobilized-regulatory $\mathrm{T}$ cells promote liver tumor recurrence after transplantation. J. Hepatol. 2016, 65, 944-952. [CrossRef] [PubMed]

143. Chen, X.; Takemoto, Y.; Deng, H.; Middelhoff, M.; Friedman, R.A.; Chu, T.H.; Churchill, M.J.; Ma, Y.; Nagar, K.K.; Tailor, Y.H.; et al. Histidine decarboxylase (HDC)-expressing granulocytic myeloid cells induce and recruit Foxp3+ regulatory $\mathrm{T}$ cells in murine colon cancer. Oncoimmunology 2017, 6, e1290034. [CrossRef] [PubMed]

144. Santagata, S.; Napolitano, M.; D’Alterio, C.; Desicato, S.; Maro, S.D.; Marinelli, L.; Fragale, A.; Buoncervello, M.; Persico, F.; Gabriele, L.; et al. Targeting CXCR4 reverts the suppressive activity of T-regulatory cells in renal cancer. Oncotarget 2017, 8 , 77110-77120. [CrossRef] [PubMed]

145. Deng, S.; Deng, Q.; Zhang, Y.; Ye, H.; Yu, X.; Zhang, Y.; Han, G.Y.; Luo, P.; Wu, M.; Yu, Y.; et al. Non-platelet-derived CXCL4 differentially regulates cytotoxic and regulatory $\mathrm{T}$ cells through $\mathrm{CXCR} 3$ to suppress the immune response to colon cancer. Cancer Lett. 2019, 443, 1-12. [CrossRef]

146. Wang, R.; Feng, W.; Wang, H.; Wang, L.; Yang, X.; Yang, F.; Zhang, Y.; Liu, X.; Zhang, D.; Ren, Q.; et al. Blocking migration of regulatory $\mathrm{T}$ cells to leukemic hematopoietic microenvironment delays disease progression in mouse leukemia model. Cancer Lett. 2020, 469, 151-161. [CrossRef]

147. Augsten, M.; Hägglöf, C.; Olsson, E.; Stolz, C.; Tsagozis, P.; Levchenko, T.; Frederick, M.J.; Borg, A.; Micke, P.; Egevad, L.; et al. CXCL14 is an autocrine growth factor for fibroblasts and acts as a multi-modal stimulator of prostate tumor growth. Proc. Natl. Acad. Sci. USA 2009, 106, 3414-3419. [CrossRef]

148. Starnes, T.; Rasila, K.K.; Robertson, M.J.; Brahmi, Z.; Dahl, R.; Christopherson, K.; Hromas, R. The chemokine CXCL14 (BRAK) stimulates activated NK cell migration: Implications for the downregulation of CXCL14 in malignancy. Exp. Hematol. 2006, 34, 1101-1105. [CrossRef]

149. Mueller, A.; Meiser, A.; McDonagh, E.M.; Fox, J.M.; Petit, S.J.; Xanthou, G.; Williams, T.J.; Pease, J.E. CXCL4-induced migration of activated T lymphocytes is mediated by the chemokine receptor CXCR3. J. Leukoc. Biol. 2008, 83, 875-882. [CrossRef]

150. Kee, J.Y.; Ito, A.; Hojo, S.; Hashimoto, I.; Igarashi, Y.; Tsukada, K.; Irimura, T.; Shibahara, N.; Nakayama, T.; Yoshie, O.; et al. Chemokine CXCL16 suppresses liver metastasis of colorectal cancer via augmentation of tumor-infiltrating natural killer T cells in a murine model. Oncol. Rep. 2013, 29, 975-982. [CrossRef]

151. Tan, K.W.; Evrard, M.; Tham, M.; Hong, M.; Huang, C.; Kato, M.; Prevost-Blondel, A.; Donnadieu, E.; Ng, L.G.; Abastado, J.P. Tumor stroma and chemokines control T-cell migration into melanoma following Temozolomide treatment. Oncoimmunology 2015, 4, e978709. [CrossRef] [PubMed]

152. Cicchini, L.; Westrich, J.A.; Xu, T.; Vermeer, D.W.; Berger, J.N.; Clambey, E.T.; Lee, D.; Song, J.I.; Lambert, P.F.; Greer, R.O.; et al. Suppression of Antitumor Immune Responses by Human Papillomavirus through Epigenetic Downregulation of CXCL14. mBio 2016, 7, e00270-16. [CrossRef] [PubMed]

153. Mossanen, J.C.; Kohlhepp, M.; Wehr, A.; Krenkel, O.; Liepelt, A.; Roeth, A.A.; Möckel, D.; Heymann, F.; Lammers, T.; Gassler, N.; et al. CXCR6 Inhibits Hepatocarcinogenesis by Promoting Natural Killer T- and CD4+ T-Cell-Dependent Control of Senescence. Gastroenterology 2019, 156, 1877-1889.e4. [CrossRef] [PubMed] 
154. Huang, G.; Tao, L.; Shen, S.; Chen, L. Hypoxia induced CCL28 promotes angiogenesis in lung adenocarcinoma by targeting CCR3 on endothelial cells. Sci. Rep. 2016, 6, 27152. [CrossRef]

155. Hatfield, K.J.; Bedringsaas, S.L.; Ryningen, A.; Gjertsen, B.T.; Bruserud, O. Hypoxia increases HIF-1 $\alpha$ expression and constitutive cytokine release by primary human acute myeloid leukaemia cells. Eur. Cytokine Netw. 2010, 21, 154-164.

156. Plotkin, B.J.; Sigar, I.M.; Swartzendruber, J.A.; Kaminski, A.; Davis, J. Differential expression of cytokines and receptor expression during anoxic growth. BMC Res. Notes 2018, 11, 406. [CrossRef]

157. Ye, L.Y.; Chen, W.; Bai, X.L.; Xu, X.Y.; Zhang, Q.; Xia, X.F.; Sun, X.; Li, G.G.; Hu, Q.D.; Fu, Q.H.; et al. Hypoxia-Induced Epithelial-to-Mesenchymal Transition in Hepatocellular Carcinoma Induces an Immunosuppressive Tumor Microenvironment to Promote Metastasis. Cancer Res. 2016, 76, 818-830. [CrossRef]

158. Triner, D.; Xue, X.; Schwartz, A.J.; Jung, I.; Colacino, J.A.; Shah, Y.M. Epithelial Hypoxia-Inducible Factor $2 \alpha$ Facilitates the Progression of Colon Tumors through Recruiting Neutrophils. Mol. Cell Biol. 2017, 37, e00481-16. [CrossRef]

159. Fang, H.Y.; Hughes, R.; Murdoch, C.; Coffelt, S.B.; Biswas, S.K.; Harris, A.L.; Johnson, R.S.; Imityaz, H.Z.; Simon, M.C.; Fredlund, E.; et al. Hypoxia-inducible factors 1 and 2 are important transcriptional effectors in primary macrophages experiencing hypoxia. Blood 2009, 114, 844-859. [CrossRef]

160. Wang, J.; Yu, F.; Jia, X.; Iwanowycz, S.; Wang, Y.; Huang, S.; Ai, W.; Fan, D. MicroRNA-155 deficiency enhances the recruitment and functions of myeloid-derived suppressor cells in tumor microenvironment and promotes solid tumor growth. Int. J. Cancer 2015, 136, E602-E613.

161. Imtiyaz, H.Z.; Williams, E.P.; Hickey, M.M.; Patel, S.A.; Durham, A.C.; Yuan, L.J.; Hammond, R.; Gimotty, P.A.; Keith, B.; Simon, M.C. Hypoxia-inducible factor 2alpha regulates macrophage function in mouse models of acute and tumor inflammation. J. Clin. Investig. 2010, 120, 2699-2714. [CrossRef] [PubMed]

162. Blengio, F.; Raggi, F.; Pierobon, D.; Cappello, P.; Eva, A.; Giovarelli, M.; Varesio, L.; Bosco, M.C. The hypoxic environment reprograms the cytokine/chemokine expression profile of human mature dendritic cells. Immunobiology 2013, 218, 76-89. [CrossRef] [PubMed]

163. Huh, Y.H.; Lee, G.; Lee, K.B.; Koh, J.T.; Chun, J.S.; Ryu, J.H. HIF-2 $\alpha$-induced chemokines stimulate motility of fibroblast-like synoviocytes and chondrocytes into the cartilage-pannus interface in experimental rheumatoid arthritis mouse models. Arthritis Res. Ther. 2015, 17, 302. [CrossRef] [PubMed]

164. Bosco, M.C.; Puppo, M.; Santangelo, C.; Anfosso, L.; Pfeffer, U.; Fardin, P.; Battaglia, F.; Varesio, L. Hypoxia modifies the transcriptome of primary human monocytes: Modulation of novel immune-related genes and identification of CC-chemokine ligand 20 as a new hypoxia-inducible gene. J. Immunol. 2006, 177, 1941-1955. [CrossRef] [PubMed]

165. Samy, Z.A.; Al-Abdullah, L.; Turcani, M.; Craik, J.; Redzic, Z. Rat astrocytes during anoxia: Secretome profile of cytokines and chemokines. Brain Behav. 2018, 8, e01013. [CrossRef] [PubMed]

166. Tripathi, C.; Tewari, B.N.; Kanchan, R.K.; Baghel, K.S.; Nautiyal, N.; Shrivastava, R.; Kaur, H.; Bhatt, M.L.; Bhadauria, S. Macrophages are recruited to hypoxic tumor areas and acquire a pro-angiogenic M2-polarized phenotype via hypoxic cancer cell derived cytokines Oncostatin M and Eotaxin. Oncotarget 2014, 5, 5350-5368. [CrossRef] [PubMed]

167. Chen, X.J.; Deng, Y.R.; Wang, Z.C.; Wei, W.F.; Zhou, C.F.; Zhang, Y.M.; Yan, R.M.; Liang, L.J.; Zhong, M.; Liang, L.; et al. Hypoxia-induced ZEB1 promotes cervical cancer progression via CCL8-dependent tumour-associated macrophage recruitment. Cell Death Dis. 2019, 10, 508. [CrossRef]

168. Tian, H.; Huang, P.; Zhao, Z.; Tang, W.; Xia, J. HIF-1 $\alpha$ plays a role in the chemotactic migration of hepatocarcinoma cells through the modulation of CXCL6 expression. Cell Physiol. Biochem. 2014, 34, 1536-1546. [CrossRef]

169. Xie, F.; Liu, L.B.; Shang, W.Q.; Chang, K.K.; Meng, Y.H.; Mei, J.; Yu, J.J.; Li, D.J.; Li, M.Q. The infiltration and functional regulation of eosinophils induced by TSLP promote the proliferation of cervical cancer cell. Cancer Lett. 2015, 364, 106-117. [CrossRef]

170. Rofstad, E.K.; Halsør, E.F. Hypoxia-associated spontaneous pulmonary metastasis in human melanoma xenografts: Involvement of microvascular hot spots induced in hypoxic foci by interleukin 8. Br. J. Cancer 2002, 86, 301-308. [CrossRef]

171. Rofstad, E.K.; Mathiesen, B.; Henriksen, K.; Kindem, K.; Galappathi, K. The tumor bed effect: Increased metastatic dissemination from hypoxia-induced up-regulation of metastasis-promoting gene products. Cancer Res. 2005, 65, 2387-2396. [CrossRef] [PubMed]

172. Shi, Q.; Abbruzzese, J.L.; Huang, S.; Fidler, I.J.; Xiong, Q.; Xie, K. Constitutive and inducible interleukin 8 expression by hypoxia and acidosis renders human pancreatic cancer cells more tumorigenic and metastatic. Clin. Cancer Res. 1999, 5, 3711-3721. [PubMed]

173. Xu, L.; Xie, K.; Mukaida, N.; Matsushima, K.; Fidler, I.J. Hypoxia-induced elevation in interleukin-8 expression by human ovarian carcinoma cells. Cancer Res. 1999, 59, 5822-5829. [PubMed]

174. Desbaillets, I.; Diserens, A.C.; Tribolet, N.; Hamou, M.F.; Van Meir, E.G. Upregulation of interleukin 8 by oxygen-deprived cells in glioblastoma suggests a role in leukocyte activation, chemotaxis, and angiogenesis. J. Exp. Med. 1997, 186, 1201-1212. [CrossRef]

175. Heinzman, J.M.; Brower, S.L.; Bush, J.E. Comparison of angiogenesis-related factor expression in primary tumor cultures under normal and hypoxic growth conditions. Cancer Cell Int. 2008, 8, 11. [CrossRef]

176. Shi, Q.; Le, X.; Wang, B.; Xiong, Q.; Abbruzzese, J.L.; Xie, K. Regulation of interleukin-8 expression by cellular pH in human pancreatic adenocarcinoma cells. J. Interferon. Cytokine Res. 2000, 20, 1023-1028. [CrossRef]

177. Voss, M.J.; Möller, M.F.; Powe, D.G.; Niggemann, B.; Zänker, K.S.; Entschladen, F. Luminal and basal-like breast cancer cells show increased migration induced by hypoxia, mediated by an autocrine mechanism. BMC Cancer 2011, 11, 158. [CrossRef]

178. Vodovotz, Y.; Simmons, R.L.; Barclay, D.; Yin, J.; Jefferson, B.S.; Zamora, R. Decoding the secreted inflammatory response of primary human hepatocytes to hypoxic stress in vitro. Ann. Transl. Med. 2019, 7, 371. [CrossRef] 
179. Bronkhorst, I.H.; Jehs, T.M.; Dijkgraaf, E.M.; Luyten, G.P.; van der Velden, P.A.; van der Burg, S.H.; Jager, M.J. Effect of hypoxic stress on migration and characteristics of monocytes in uveal melanoma. JAMA Ophthalmol. 2014, 132, 614-621. [CrossRef]

180. Kunz, M.; Hartmann, A.; Flory, E.; Toksoy, A.; Koczan, D.; Thiesen, H.J.; Mukaida, N.; Neumann, M.; Rapp, U.R.; Bröcker, E.B.; et al. Anoxia-induced up-regulation of interleukin-8 in human malignant melanoma. A potential mechanism for high tumor aggressiveness. Am. J. Pathol. 1999, 155, 753-763. [CrossRef]

181. Xu, L.; Pathak, P.S.; Fukumura, D. Hypoxia-induced activation of p38 mitogen-activated protein kinase and phosphatidylinositol $3^{\prime}$-kinase signaling pathways contributes to expression of interleukin 8 in human ovarian carcinoma cells. Clin. Cancer Res. 2004, 10, 701-707. [CrossRef] [PubMed]

182. Shi, Q.; Le, X.; Abbruzzese, J.L.; Wang, B.; Mujaida, N.; Matsushima, K.; Huang, S.; Xiong, Q.; Xie, K. Cooperation between transcription factor AP-1 and NF-kappaB in the induction of interleukin-8 in human pancreatic adenocarcinoma cells by hypoxia. J. Interferon. Cytokine Res. 1999, 19, 1363-1371. [CrossRef] [PubMed]

183. Wysoczynski, M.; Shin, D.M.; Kucia, M.; Ratajczak, M.Z. Selective upregulation of interleukin-8 by human rhabdomyosarcomas in response to hypoxia: Therapeutic implications. Int. J. Cancer 2010, 126, 371-381. [CrossRef] [PubMed]

184. Desbaillets, I.; Diserens, A.C.; de Tribolet, N.; Hamou, M.F.; Van Meir, E.G. Regulation of interleukin-8 expression by reduced oxygen pressure in human glioblastoma. Oncogene 1999, 18, 1447-1456. [CrossRef]

185. Karashima, T.; Sweeney, P.; Kamat, A.; Huang, S.; Kim, S.J.; Bar-Eli, M.; McConkey, D.J.; Dinney, C.P. Nuclear factor-kappaB mediates angiogenesis and metastasis of human bladder cancer through the regulation of interleukin-8. Clin. Cancer Res. 2003, 9 , 2786-2797.

186. Fei, M.; Guan, J.; Xue, T.; Qin, L.; Tang, C.; Cui, G.; Wang, Y.; Gong, H.; Feng, W. Hypoxia promotes the migration and invasion of human hepatocarcinoma cells through the HIF-1 $\alpha$-IL-8-Akt axis. Cell Mol. Biol. Lett. 2018, 23, 46. [CrossRef]

187. Feng, W.; Xue, T.; Huang, S.; Shi, Q.; Tang, C.; Cui, G.; Yang, G.; Gong, H.; Guo, H. HIF-1 $\alpha$ promotes the migration and invasion of hepatocellular carcinoma cells via the IL-8-NF-kB axis. Cell Mol. Biol. Lett. 2018, 23, 26. [CrossRef]

188. Mizukami, Y.; Jo, W.S.; Duerr, E.M.; Gala, M.; Li, J.; Zhang, X.; Zimmer, M.A.; Iliopoulos, O.; Zukerberg, L.R.; Kohgo, Y.; et al. Induction of interleukin-8 preserves the angiogenic response in HIF-1alpha-deficient colon cancer cells. Nat. Med. 2005, 11, 992-997. [CrossRef]

189. Herwartz, C.; Castillo-Juárez, P.; Schröder, L.; Barron, B.L.; Steger, G. The Transcription Factor ZNF395 Is Required for the Maximal Hypoxic Induction of Proinflammatory Cytokines in U87-MG Cells. Mediat. Inflamm. 2015, 2015, 804264. [CrossRef]

190. Timani, K.A.; Liu, Y.; Fan, Y.; Mohammad, K.S.; He, J.J. Tip110 Regulates the Cross Talk between p53 and Hypoxia-Inducible Factor $1 \alpha$ under Hypoxia and Promotes Survival of Cancer Cells. Mol. Cell Biol. 2015, 35, 2254-2264. [CrossRef]

191. Timani, K.A.; Győrffy, B.; Liu, Y.; Mohammad, K.S.; He, J.J. Tip110/SART3 regulates IL-8 expression and predicts the clinical outcomes in melanoma. Mol. Cancer 2018, 17, 124. [CrossRef] [PubMed]

192. Hsiao, K.Y.; Chang, N.; Lin, S.C.; Li, Y.H.; Wu, M.H. Inhibition of dual specificity phosphatase-2 by hypoxia promotes interleukin8-mediated angiogenesis in endometriosis. Hum. Reprod. 2014, 29, 2747-2755. [CrossRef] [PubMed]

193. Lin, S.C.; Hsiao, K.Y.; Chang, N.; Hou, P.C.; Tsai, S.J. Loss of dual-specificity phosphatase-2 promotes angiogenesis and metastasis via up-regulation of interleukin-8 in colon cancer. J. Pathol. 2017, 241, 638-648. [CrossRef] [PubMed]

194. Chiang, Y.Y. Hepatocyte growth factor induces hypoxia-related interleukin-8 expression in lung adenocarcinoma cells. Mol. Carcinog. 2009, 48, 662-670. [CrossRef] [PubMed]

195. Polotsky, V.Y.; Savransky, V.; Bevans-Fonti, S.; Reinke, C.; Li, J.; Grigoryev, D.N.; Shimoda, L.A. Intermittent and sustained hypoxia induce a similar gene expression profile in human aortic endothelial cells. Physiol. Genom. 2010, 41, 306-314. [CrossRef] [PubMed]

196. Glynn, P.C.; Henney, E.; Hall, I.P. The selective CXCR2 antagonist SB272844 blocks interleukin-8 and growth-related oncogenealpha-mediated inhibition of spontaneous neutrophil apoptosis. Pulm. Pharmacol. Ther. 2002, 15, 103-110. [CrossRef]

197. Dyugovskaya, L.; Polyakov, A.; Ginsberg, D.; Lavie, P.; Lavie, L. Molecular pathways of spontaneous and TNF-\{alpha\}-mediated neutrophil apoptosis under intermittent hypoxia. Am. J. Respir. Cell Mol. Biol. 2011, 45, 154-162. [CrossRef]

198. Galindo, M.; Santiago, B.; Alcami, J.; Rivero, M.; Martín-Serrano, J.; Pablos, J.L. Hypoxia induces expression of the chemokines monocyte chemoattractant protein-1 (MCP-1) and IL-8 in human dermal fibroblasts. Clin. Exp. Immunol. 2001, 123, 36-41. [CrossRef]

199. Higashihara, H.; Kokura, S.; Imamoto, E.; Ueda, M.; Naito, Y.; Yoshida, N.; Yoshikawa, T. Hypoxia-reoxygenation enhances interleukin-8 production from U937 human monocytic cells. Redox Rep. 2004, 9, 365-369. [CrossRef]

200. Chen, J.J.; Yao, P.L.; Yuan, A.; Hong, T.M.; Shun, C.T.; Kuo, M.L.; Lee, Y.C.; Yang, P.C. Up-regulation of tumor interleukin-8 expression by infiltrating macrophages: Its correlation with tumor angiogenesis and patient survival in non-small cell lung cancer. Clin. Cancer Res. 2003, 9, 729-737.

201. Hirani, N.; Antonicelli, F.; Strieter, R.M.; Wiesener, M.S.; Ratcliffe, P.J.; Haslett, C.; Donnelly, S.C. The regulation of interleukin-8 by hypoxia in human macrophages-a potential role in the pathogenesis of the acute respiratory distress syndrome (ARDS). Mol. Med. 2001, 7, 685-697. [CrossRef] [PubMed]

202. Delprat, V.; Tellier, C.; Demazy, C.; Raes, M.; Feron, O.; Michiels, C. Cycling hypoxia promotes a pro-inflammatory phenotype in macrophages via JNK/p65 signaling pathway. Sci. Rep. 2020, 10, 882. [CrossRef] [PubMed]

203. Karakurum, M.; Shreeniwas, R.; Chen, J.; Pinsky, D.; Yan, S.D.; Anderson, M.; Sunouchi, K.; Major, J.; Hamilton, T.; Kuwabara, K.; et al. Hypoxic induction of interleukin-8 gene expression in human endothelial cells. J. Clin. Investig. 1994, 93, 1564-1570. [CrossRef] [PubMed] 
204. Kim, K.S.; Rajagopal, V.; Gonsalves, C.; Johnson, C.; Kalra, V.K. A novel role of hypoxia-inducible factor in cobalt chloride- and hypoxia-mediated expression of IL-8 chemokine in human endothelial cells. J. Immunol. 2006, 177, 7211-7224. [CrossRef] [PubMed]

205. Endler, A.; Chen, L.; Li, Q.; Uchida, K.; Hashimoto, T.; Lu, L.; Xu, G.T.; Shibasaki, F. Int6/eIF3e silenced HIF2 $\alpha$ stabilization enhances migration and tube formation of HUVECs via IL-6 and IL-8 signaling. Cytokine 2013, 62, 115-122. [CrossRef]

206. Loboda, A.; Jazwa, A.; Jozkowicz, A.; Molema, G.; Dulak, J. Angiogenic transcriptome of human microvascular endothelial cells: Effect of hypoxia, modulation by atorvastatin. Vascul. Pharmacol. 2006, 44, 206-214. [CrossRef]

207. Loboda, A.; Stachurska, A.; Florczyk, U.; Rudnicka, D.; Jazwa, A.; Wegrzyn, J.; Kozakowska, M.; Stalinska, K.; Poellinger, L.; Levonen, A.L.; et al. HIF-1 induction attenuates Nrf2-dependent IL-8 expression in human endothelial cells. Antioxid. Redox Signal. 2009, 11, 1501-1517. [CrossRef]

208. Florczyk, U.; Czauderna, S.; Stachurska, A.; Tertil, M.; Nowak, W.; Kozakowska, M.; Poellinger, L.; Jozkowicz, A.; Loboda, A.; Dulak, J. Opposite effects of HIF- $1 \alpha$ and HIF- $2 \alpha$ on the regulation of IL-8 expression in endothelial cells. Free Radic. Biol. Med. 2011, 51, 1882-1892. [CrossRef]

209. Liu, L.B.; Xie, F.; Chang, K.K.; Li, M.Q.; Meng, Y.H.; Wang, X.H.; Li, H.; Li, D.J.; Yu, J.J. Hypoxia promotes the proliferation of cervical carcinoma cells through stimulating the secretion of IL-8. Int. J. Clin. Exp. Pathol. 2014, 7, 575-583.

210. Maxwell, P.J.; Gallagher, R.; Seaton, A.; Wilson, C.; Scullin, P.; Pettigrew, J.; Stratford, I.J.; Williams, K.J.; Johnston, P.G.; Waugh, D.J. HIF-1 and NF-kappaB-mediated upregulation of CXCR1 and CXCR2 expression promotes cell survival in hypoxic prostate cancer cells. Oncogene 2007, 26, 7333-7345. [CrossRef]

211. Moldobaeva, A.; Wagner, E.M. Difference in proangiogenic potential of systemic and pulmonary endothelium: Role of CXCR2. Am. J. Physiol. Lung Cell Mol. Physiol. 2005, 288, L1117-L1123. [CrossRef] [PubMed]

212. Kinoshita, H.; Yashiro, M.; Fukuoka, T.; Hasegawa, T.; Morisaki, T.; Kasashima, H.; Masuda, G.; Noda, S.; Hirakawa, K. Diffuse-type gastric cancer cells switch their driver pathways from FGFR2 signaling to SDF1/CXCR4 axis in hypoxic tumor microenvironments. Carcinogenesis 2015, 36, 1511-1520. [CrossRef] [PubMed]

213. Grutkoski, P.S.; Graeber, C.T.; D'Amico, R.; Keeping, H.; Simms, H.H. Regulation of IL-8RA (CXCR1) expression in polymorphonuclear leukocytes by hypoxia/reoxygenation. J. Leukoc. Biol. 1999, 65, 171-178. [CrossRef] [PubMed]

214. Victor, N.; Ivy, A.; Jiang, B.H.; Agani, F.H. Involvement of HIF-1 in invasion of Mum2B uveal melanoma cells. Clin. Exp. Metastasis 2006, 23, 87-96. [CrossRef]

215. Xia, J.B.; Liu, G.H.; Chen, Z.Y.; Mao, C.Z.; Zhou, D.C.; Wu, H.Y.; Park, K.S.; Zhao, H.; Kim, S.K.; Cai, D.Q.; et al. Hypoxia/ischemia promotes CXCL10 expression in cardiac microvascular endothelial cells by NFkB activation. Cytokine 2016, 81, 63-70. [CrossRef]

216. Konishi, H.; Shirabe, K.; Nakagawara, H.; Harimoto, N.; Yamashita, Y.; Ikegami, T.; Yoshizumi, T.; Soejima, Y.; Oda, Y.; Maehara, Y. Suppression of silent information regulator 1 activity in noncancerous tissues of hepatocellular carcinoma: Possible association with non-B non-C hepatitis pathogenesis. Cancer Sci. 2015, 106, 542-549. [CrossRef]

217. Marotta, D.; Karar, J.; Jenkins, W.T.; Kumanova, M.; Jenkins, K.W.; Tobias, J.W.; Baldwin, D.; Hatzigeorgiou, A.; Alexiou, P.; Evans, S.M.; et al. In vivo profiling of hypoxic gene expression in gliomas using the hypoxia marker EF5 and laser-capture microdissection. Cancer Res. 2011, 71, 779-789. [CrossRef]

218. Ullah, K.; Rosendahl, A.H.; Izzi, V.; Bergmann, U.; Pihlajaniemi, T.; Mäki, J.M.; Myllyharju, J. Hypoxia-inducible factor prolyl-4hydroxylase- 1 is a convergent point in the reciprocal negative regulation of NF-kB and p53 signaling pathways. Sci. Rep. 2017, 7, 17220. [CrossRef]

219. Utsumi, T.; Suyama, T.; Imamura, Y.; Fuse, M.; Sakamoto, S.; Nihei, N.; Ueda, T.; Suzuki, H.; Seki, N.; Ichikawa, T. The association of CXCR3 and renal cell carcinoma metastasis. J. Urol. 2014, 192, 567-574. [CrossRef]

220. Muñoz-Sánchez, J.; Chánez-Cárdenas, M.E. The use of cobalt chloride as a chemical hypoxia model. J. Appl. Toxicol. 2019, 39, 556-570. [CrossRef]

221. Arvidsson, Y.; Bergström, A.; Arvidsson, L.; Kristiansson, E.; Ahlman, H.; Nilsson, O. Hypoxia stimulates CXCR4 signalling in ileal carcinoids. Endocr. Relat. Cancer 2010, 17, 303-316. [CrossRef] [PubMed]

222. Noman, M.Z.; Janji, B.; Hu, S.; Wu, J.C.; Martelli, F.; Bronte, V.; Chouaib, S. Tumor-Promoting Effects of Myeloid-Derived Suppressor Cells Are Potentiated by Hypoxia-Induced Expression of miR-210. Cancer Res. 2015, 75, 3771-3787. [CrossRef] [PubMed]

223. Zagzag, D.; Krishnamachary, B.; Yee, H.; Okuyama, H.; Chiriboga, L.; Ali, M.A.; Melamed, J.; Semenza, G.L. Stromal cell-derived factor-1alpha and CXCR4 expression in hemangioblastoma and clear cell-renal cell carcinoma: Von Hippel-Lindau loss-of-function induces expression of a ligand and its receptor. Cancer Res. 2005, 65, 6178-6188. [CrossRef] [PubMed]

224. Tabatabai, G.; Frank, B.; Möhle, R.; Weller, M.; Wick, W. Irradiation and hypoxia promote homing of haematopoietic progenitor cells towards gliomas by TGF-beta-dependent HIF-1alpha-mediated induction of CXCL12. Brain 2006, 129, 2426-2435. [CrossRef] [PubMed]

225. Zhao, D.; Najbauer, J.; Garcia, E.; Metz, M.Z.; Gutova, M.; Glackin, C.A.; Kim, S.U.; Aboody, K.S. Neural stem cell tropism to glioma: Critical role of tumor hypoxia. Mol. Cancer Res. 2008, 6, 1819-1829. [CrossRef]

226. Komatani, H.; Sugita, Y.; Arakawa, F.; Ohshima, K.; Shigemori, M. Expression of CXCL12 on pseudopalisading cells and proliferating microvessels in glioblastomas: An accelerated growth factor in glioblastomas. Int. J. Oncol. $2009,34,665-672$.

227. Martin, S.K.; Diamond, P.; Williams, S.A.; To, L.B.; Peet, D.J.; Fujii, N.; Gronthos, S.; Harris, A.L.; Zannettino, A.C. Hypoxiainducible factor-2 is a novel regulator of aberrant CXCL12 expression in multiple myeloma plasma cells. Haematologica 2010, 95, 776-784. [CrossRef] 
228. Kryczek, I.; Lange, A.; Mottram, P.; Alvarez, X.; Cheng, P.; Hogan, M.; Moons, L.; Wei, S.; Zou, L.; Machelon, V.; et al. CXCL12 and vascular endothelial growth factor synergistically induce neoangiogenesis in human ovarian cancers. Cancer Res. 2005, $65,465-472$.

229. Jin, F.; Brockmeier, U.; Otterbach, F.; Metzen, E. New insight into the SDF-1/CXCR4 axis in a breast carcinoma model: Hypoxia-induced endothelial SDF-1 and tumor cell CXCR4 are required for tumor cell intravasation. Mol. Cancer Res. 2012, 10, 1021-1031. [CrossRef]

230. Sun, Y.; Xiong, X.; Wang, X. RELA promotes hypoxia-induced angiogenesis in human umbilical vascular endothelial cells via LINC01693/miR-302d/CXCL12 axis. J. Cell Biochem. 2019, 120, 12549-12558.

231. Ceradini, D.J.; Kulkarni, A.R.; Callaghan, M.J.; Tepper, O.M.; Bastidas, N.; Kleinman, M.E.; Capla, J.M.; Galiano, R.D.; Levine, J.P.; Gurtner, G.C. Progenitor cell trafficking is regulated by hypoxic gradients through HIF-1 induction of SDF-1. Nat. Med. 2004, 10, 858-864. [CrossRef] [PubMed]

232. Strickland, J.; Garrison, D.; Copple, B.L. Hypoxia upregulates Cxcl12 in hepatocytes by a complex mechanism involving hypoxia-inducible factors and transforming growth factor- $\beta$. Cytokine 2020, 127, 154986. [CrossRef] [PubMed]

233. Matteucci, E.; Locati, M.; Desiderio, M.A. Hepatocyte growth factor enhances CXCR4 expression favoring breast cancer cell invasiveness. Exp. Cell Res. 2005, 310, 176-185. [CrossRef] [PubMed]

234. Seo, Y.J.; Koh, S.H.; Kang, H.J.; Shin, H.Y.; Jeong, G.; Ahn, H.S. Hypoxia inhibits the SDF-1-dependent migration of human leukemic cell line HL-60 via blocking of Akt activation. Biochem. Biophys. Res. Commun. 2007, 364, 388-394. [CrossRef] [PubMed]

235. Cronin, P.A.; Wang, J.H.; Redmond, H.P. Hypoxia increases the metastatic ability of breast cancer cells via upregulation of CXCR4. BMC Cancer 2010, 10, 225. [CrossRef] [PubMed]

236. Tafani, M.; Russo, A.; Di Vito, M.; Sale, P.; Pellegrini, L.; Schito, L.; Gentileschi, S.; Bracaglia, R.; Marandino, F.; Garaci, E.; et al. Up-regulation of pro-inflammatory genes as adaptation to hypoxia in MCF-7 cells and in human mammary invasive carcinoma microenvironment. Cancer Sci. 2010, 101, 1014-1023. [CrossRef]

237. Jamaludin, S.Y.N.; Azimi, I.; Davis, F.M.; Peters, A.A.; Gonda, T.J.; Thompson, E.W.; Roberts-Thomson, S.J.; Monteith, G.R. Assessment of CXC ligand 12-mediated calcium signalling and its regulators in basal-like breast cancer cells. Oncol. Lett. 2018, 15, 4289-4295. [CrossRef]

238. Zhang, M.; Gao, C.E.; Chen, W.L.; Tang, Y.Y.; Nie, J.Y.; Shen, L.D.; Ma, X.; Chen, D.D. Opposite response to hypoxia by breast cancer cells between cell proliferation and cell migration: A clue from microRNA expression profile. Oncol. Lett. 2018, 15, 2771-2780. [CrossRef]

239. Sun, X.; Wei, L.; Chen, Q.; Terek, R.M. CXCR4/SDF1 mediate hypoxia induced chondrosarcoma cell invasion through ERK signaling and increased MMP1 expression. Mol. Cancer 2010, 9, 17. [CrossRef]

240. Sun, X.; Charbonneau, C.; Wei, L.; Chen, Q.; Terek, R.M. miR-181a Targets RGS16 to Promote Chondrosarcoma Growth, Angiogenesis, and Metastasis. Mol. Cancer Res. 2015, 13, 1347-1357. [CrossRef]

241. Valsecchi, R.; Coltella, N.; Belloni, D.; Ponente, M.; Ten Hacken, E.; Scielzo, C.; Scarfò, L.; Bertilaccio, M.T.; Brambilla, P.; Lenti, E.; et al. HIF- $1 \alpha$ regulates the interaction of chronic lymphocytic leukemia cells with the tumor microenvironment. Blood 2016, 127, 1987-1997. [CrossRef] [PubMed]

242. Hongo, K.; Tsuno, N.H.; Kawai, K.; Sasaki, K.; Kaneko, M.; Hiyoshi, M.; Murono, K.; Tada, N.; Nirei, T.; Sunami, E.; et al. Hypoxia enhances colon cancer migration and invasion through promotion of epithelial-mesenchymal transition. J. Surg. Res. 2013, 182, 75-84. [CrossRef] [PubMed]

243. Romain, B.; Hachet-Haas, M.; Rohr, S.; Brigand, C.; Galzi, J.L.; Gaub, M.P.; Pencreach, E.; Guenot, D. Hypoxia differentially regulated CXCR4 and CXCR7 signaling in colon cancer. Mol. Cancer 2014, 13, 58. [CrossRef] [PubMed]

244. Oh, Y.S.; Kim, H.Y.; Song, I.C.; Yun, H.J.; Jo, D.Y.; Kim, S.; Lee, H.J. Hypoxia induces CXCR4 expression and biological activity in gastric cancer cells through activation of hypoxia-inducible factor-1 $\alpha$. Oncol. Rep. 2012, 28, 2239-2246. [CrossRef] [PubMed]

245. Zagzag, D.; Lukyanov, Y.; Lan, L.; Ali, M.A.; Esencay, M.; Mendez, O.; Yee, H.; Voura, E.B.; Newcomb, E.W. Hypoxia-inducible factor 1 and VEGF upregulate CXCR4 in glioblastoma: Implications for angiogenesis and glioma cell invasion. Lab. Investig. 2006, 86, 1221-1232. [CrossRef]

246. Zagzag, D.; Esencay, M.; Mendez, O.; Yee, H.; Smirnova, I.; Huang, Y.; Chiriboga, L.; Lukyanov, E.; Liu, M.; Newcomb, E.W. Hypoxia- and vascular endothelial growth factor-induced stromal cell-derived factor-1alpha/CXCR4 expression in glioblastomas: One plausible explanation of Scherer's structures. Am. J. Pathol. 2008, 173, 545-560. [CrossRef]

247. Hiroi, M.; Mori, K.; Sakaeda, Y.; Shimada, J.; Ohmori, Y. STAT1 represses hypoxia-inducible factor-1-mediated transcription. Biochem. Biophys. Res. Commun. 2009, 387, 806-810. [CrossRef]

248. Liu, Y.L.; Yu, J.M.; Song, X.R.; Wang, X.W.; Xing, L.G.; Gao, B.B. Regulation of the chemokine receptor CXCR4 and metastasis by hypoxia-inducible factor in non small cell lung cancer cell lines. Cancer Biol. Ther. 2006, 5, 1320-1326. [CrossRef]

249. Kang, N.; Choi, S.Y.; Kim, B.N.; Yeo, C.D.; Park, C.K.; Kim, Y.K.; Kim, T.J.; Lee, S.B.; Lee, S.H.; Park, J.Y.; et al. Hypoxia-induced cancer stemness acquisition is associated with CXCR4 activation by its aberrant promoter demethylation. BMC Cancer 2019, 19, 148. [CrossRef]

250. Schutyser, E.; Su, Y.; Yu, Y.; Gouwy, M.; Zaja-Milatovic, S.; Van Damme, J.; Richmond, A. Hypoxia enhances CXCR4 expression in human microvascular endothelial cells and human melanoma cells. Eur. Cytokine Netw. 2007, 18, 59-70.

251. Dong, L.; You, S.; Zhang, Q.; Osuka, S.; Devi, N.S.; Kaluz, S.; Ferguson, J.H.; Yang, H.; Chen, G.; Wang, B.; et al. Arylsulfonamide 64B Inhibits Hypoxia/HIF-Induced Expression of c-Met and CXCR4 and Reduces Primary Tumor Growth and Metastasis of Uveal Melanoma. Clin. Cancer Res. 2019, 25, 2206-2218. [CrossRef] [PubMed] 
252. Azab, A.K.; Hu, J.; Quang, P.; Azab, F.; Pitsillides, C.; Awwad, R.; Thompson, B.; Maiso, P.; Sun, J.D.; Hart, C.P.; et al. Hypoxia promotes dissemination of multiple myeloma through acquisition of epithelial to mesenchymal transition-like features. Blood 2012, 119, 5782-5794. [CrossRef] [PubMed]

253. Ishikawa, T.; Nakashiro, K.; Klosek, S.K.; Goda, H.; Hara, S.; Uchida, D.; Hamakawa, H. Hypoxia enhances CXCR4 expression by activating HIF-1 in oral squamous cell carcinoma. Oncol. Rep. 2009, 21, 707-712. [PubMed]

254. Guo, M.; Cai, C.; Zhao, G.; Qiu, X.; Zhao, H.; Ma, Q.; Tian, L.; Li, X.; Hu, Y.; Liao, B.; et al. Hypoxia promotes migration and induces CXCR4 expression via HIF-1 $\alpha$ activation in human osteosarcoma. PLoS ONE 2014, 9, e90518. [CrossRef] [PubMed]

255. Guan, G.; Zhang, Y.; Lu, Y.; Liu, L.; Shi, D.; Wen, Y.; Yang, L.; Ma, Q.; Liu, T.; Zhu, X.; et al. The HIF-1 $\alpha / C X C R 4$ pathway supports hypoxia-induced metastasis of human osteosarcoma cells. Cancer Lett. 2015, 357, 254-264. [CrossRef]

256. Marchesi, F.; Monti, P.; Leone, B.E.; Zerbi, A.; Vecchi, A.; Piemonti, L.; Mantovani, A.; Allavena, P. Increased survival, proliferation, and migration in metastatic human pancreatic tumor cells expressing functional CXCR4. Cancer Res. 2004, 64, 8420-8427. [CrossRef]

257. Sun, J.S.; Zhang, X.L.; Yang, Y.J.; Nie, Z.G.; Zhang, Y. Hypoxia promotes C-X-C chemokine receptor type 4 expression through microRNA-150 in pancreatic cancer cells. Oncol. Lett. 2015, 10, 835-840. [CrossRef]

258. Pan, J.; Mestas, J.; Burdick, M.D.; Phillips, R.J.; Thomas, G.V.; Reckamp, K.; Belperio, J.A.; Strieter, R.M. Stromal derived factor-1 (SDF-1/CXCL12) and CXCR4 in renal cell carcinoma metastasis. Mol. Cancer 2006, 5, 56. [CrossRef]

259. Tang, M.; Yang, Y.; Yu, J.; Wu, N.; Chen, P.; Xu, L.; Wang, Q.; Xu, Z.; Ge, J.; Yu, K.; et al. Discordant mRNA and protein expression of CXCR4 under in vitro CoCl2-induced hypoxic conditions. Biochem. Biophys. Res. Commun. 2017, 484, 285-291. [CrossRef]

260. Kim, S.W.; Kim, H.Y.; Song, I.C.; Jin, S.A.; Lee, H.J.; Yun, H.J.; Kim, S.; Jo, D.Y. Cytoplasmic trapping of CXCR4 in hepatocellular carcinoma cell lines. Cancer Res. Treat. 2008, 40, 53-61. [CrossRef]

261. Esencay, M.; Sarfraz, Y.; Zagzag, D. CXCR7 is induced by hypoxia and mediates glioma cell migration towards SDF-1 $\alpha$. BMC Cancer 2013, 13, 347. [CrossRef] [PubMed]

262. Kim, H.Y.; Lee, S.Y.; Kim, D.Y.; Moon, J.Y.; Choi, Y.S.; Song, I.C.; Lee, H.J.; Yun, H.J.; Kim, S.; Jo, D.Y. Expression and functional roles of the chemokine receptor CXCR7 in acute myeloid leukemia cells. Blood Res. 2015, 50, 218-226. [CrossRef] [PubMed]

263. Schioppa, T.; Uranchimeg, B.; Saccani, A.; Biswas, S.K.; Doni, A.; Rapisarda, A.; Bernasconi, S.; Saccani, S.; Nebuloni, M.; Vago, L.; et al. Regulation of the chemokine receptor CXCR4 by hypoxia. J. Exp. Med. 2003, 198, 1391-1402. [CrossRef] [PubMed]

264. Huang, X.; Zhou, J.; Liu, J.; Tang, B.; Zhao, F.; Qu, Y. Biological characteristics of prostate cancer cells are regulated by hypoxiainducible factor $1 \alpha$. Oncol. Lett. 2014, 8, 1217-1221. [CrossRef] [PubMed]

265. Micucci, C.; Matacchione, G.; Valli, D.; Orciari, S.; Catalano, A. HIF2 $\alpha$ is involved in the expansion of CXCR4-positive cancer stem-like cells in renal cell carcinoma. Br. J. Cancer 2015, 113, 1178-1185. [CrossRef]

266. Dunn, L.K.; Mohammad, K.S.; Fournier, P.G.; McKenna, C.R.; Davis, H.W.; Niewolna, M.; Peng, X.H.; Chirgwin, J.M.; Guise, T.A. Hypoxia and TGF-beta drive breast cancer bone metastases through parallel signaling pathways in tumor cells and the bone microenvironment. PLoS ONE 2009, 4, e6896. [CrossRef]

267. Tu, T.C.; Nagano, M.; Yamashita, T.; Hamada, H.; Ohneda, K.; Kimura, K.; Ohneda, O. A Chemokine Receptor, CXCR4, Which Is Regulated by Hypoxia-Inducible Factor $2 \alpha$, Is Crucial for Functional Endothelial Progenitor Cells Migration to Ischemic Tissue and Wound Repair. Stem Cells Dev. 2016, 25, 266-276. [CrossRef]

268. Sun, X.; Wei, L.; Chen, Q.; Terek, R.M. MicroRNA regulates vascular endothelial growth factor expression in chondrosarcoma cells. Clin. Orthop. Relat. Res. 2015, 473, 907-913. [CrossRef]

269. Vandyke, K.; Zeissig, M.N.; Hewett, D.R.; Martin, S.K.; Mrozik, K.M.; Cheong, C.M.; Diamond, P.; To, L.B.; Gronthos, S.; Peet, D.J.; et al. HIF- $2 \alpha$ Promotes Dissemination of Plasma Cells in Multiple Myeloma by Regulating CXCL12/CXCR4 and CCR1. Cancer Res. 2017, 77, 5452-5463. [CrossRef]

270. Spinello, I.; Quaranta, M.T.; Paolillo, R.; Pelosi, E.; Cerio, A.M.; Saulle, E.; Lo Coco, F.; Testa, U.; Labbaye, C. Differential hypoxic regulation of the microRNA-146a/CXCR4 pathway in normal and leukemic monocytic cells: Impact on response to chemotherapy. Haematologica 2015, 100, 1160-1171. [CrossRef]

271. Fiegl, M.; Samudio, I.; Clise-Dwyer, K.; Burks, J.K.; Mnjoyan, Z.; Andreeff, M. CXCR4 expression and biologic activity in acute myeloid leukemia are dependent on oxygen partial pressure. Blood 2009, 113, 1504-1512. [CrossRef] [PubMed]

272. Saba, F.; Soleimani, M.; Abroun, S. New role of hypoxia in pathophysiology of multiple myeloma through miR-210. EXCLI J. 2018, 17, 647-662. [PubMed]

273. Namiki, A.; Brogi, E.; Kearney, M.; Kim, E.A.; Wu, T.; Couffinhal, T.; Varticovski, L.; Isner, J.M. Hypoxia induces vascular endothelial growth factor in cultured human endothelial cells. J. Biol. Chem. 1995, 270, 31189-31195. [CrossRef]

274. Scheurer, S.B.; Rybak, J.N.; Rösli, C.; Neri, D.; Elia, G. Modulation of gene expression by hypoxia in human umbilical cord vein endothelial cells: A transcriptomic and proteomic study. Proteomics 2004, 4, 1737-1760. [CrossRef] [PubMed]

275. Zeng, H.; Wei, W.; Xu, X. Chemokine (C-X-C motif) receptor 4 RNA interference inhibits bone metastasis in breast cancer. Oncol. Lett. 2014, 8, 77-81. [CrossRef]

276. Müller, A.; Homey, B.; Soto, H.; Ge, N.; Catron, D.; Buchanan, M.E.; McClanahan, T.; Murphy, E.; Yuan, W.; Wagner, S.N.; et al. Involvement of chemokine receptors in breast cancer metastasis. Nature 2001, 410, 50-56. [CrossRef]

277. Andre, F.; Xia, W.; Conforti, R.; Wei, Y.; Boulet, T.; Tomasic, G.; Spielmann, M.; Zoubir, M.; Berrada, N.; Arriagada, R.; et al. CXCR4 expression in early breast cancer and risk of distant recurrence. Oncologist 2009, 14, 1182-1188. [CrossRef]

278. Hung, C.S.; Su, H.Y.; Liang, H.H.; Lai, C.W.; Chang, Y.C.; Ho, Y.S.; Wu, C.H.; Ho, J.D.; Wei, P.L.; Chang, Y.J. High-level expression of CXCR4 in breast cancer is associated with early distant and bone metastases. Tumour Biol. 2014, 35, 1581-1588. [CrossRef] 
279. Devignes, C.S.; Aslan, Y.; Brenot, A.; Devillers, A.; Schepers, K.; Fabre, S.; Chou, J.; Casbon, A.J.; Werb, Z.; Provot, S. HIF signaling in osteoblast-lineage cells promotes systemic breast cancer growth and metastasis in mice. Proc. Natl. Acad. Sci. USA 2018, 115, E992-E1001. [CrossRef]

280. Nomura, R.; Yoshida, D.; Teramoto, A. Stromal cell-derived factor-1 expression in pituitary adenoma tissues and upregulation in hypoxia. J. Neurooncol. 2009, 94, 173-181. [CrossRef]

281. Menu, E.; Asosingh, K.; Indraccolo, S.; De Raeve, H.; Van Riet, I.; Van Valckenborgh, E.; Vande Broek, I.; Fujii, N.; Tamamura, H.; Van Camp, B.; et al. The involvement of stromal derived factor 1alpha in homing and progression of multiple myeloma in the 5TMM model. Haematologica 2006, 91, 605-612. [PubMed]

282. Pennathur-Das, R.; Levitt, L. Augmentation of in vitro human marrow erythropoiesis under physiological oxygen tensions is mediated by monocytes and T lymphocytes. Blood 1987, 69, 899-907. [CrossRef] [PubMed]

283. Asosingh, K.; De Raeve, H.; de Ridder, M.; Storme, G.A.; Willems, A.; Van Riet, I.; Van Camp, B.; Vanderkerken, K. Role of the hypoxic bone marrow microenvironment in 5T2MM murine myeloma tumor progression. Haematologica 2005, 90, 810-817. [PubMed]

284. Storti, P.; Bolzoni, M.; Donofrio, G.; Airoldi, I.; Guasco, D.; Toscani, D.; Martella, E.; Lazzaretti, M.; Mancini, C.; Agnelli, L.; et al Hypoxia-inducible factor (HIF)- $1 \alpha$ suppression in myeloma cells blocks tumoral growth in vivo inhibiting angiogenesis and bone destruction. Leukemia 2013, 27, 1697-1706. [CrossRef]

285. Bao, Y.; Wang, Z.; Liu, B.; Lu, X.; Xiong, Y.; Shi, J.; Li, P.; Chen, J.; Zhang, Z.; Chen, M.; et al. A feed-forward loop between nuclear translocation of CXCR4 and HIF-1 $\alpha$ promotes renal cell carcinoma metastasis. Oncogene 2019, 38, 881-895. [CrossRef]

286. Kusuyama, J.; Bandow, K.; Ohnishi, T.; Amir, M.S.; Shima, K.; Semba, I.; Matsuguchi, T. CXCL13 is a differentiation- and hypoxia-induced adipocytokine that exacerbates the inflammatory phenotype of adipocytes through PHLPP1 induction. Biochem. J 2019, 476, 3533-3548. [CrossRef]

287. Ammirante, M.; Shalapour, S.; Kang, Y.; Jamieson, C.A.; Karin, M. Tissue injury and hypoxia promote malignant progression of prostate cancer by inducing CXCL13 expression in tumor myofibroblasts. Proc. Natl. Acad. Sci. USA 2014, 111, 14776-14781. [CrossRef]

288. Lee, H.T.; Liu, S.P.; Lin, C.H.; Lee, S.W.; Hsu, C.Y.; Sytwu, H.K.; Hsieh, C.H.; Shyu, W.C. A Crucial Role of CXCL14 for Promoting Regulatory T Cells Activation in Stroke. Theranostics 2017, 7, 855-875. [CrossRef]

289. Yue, F.; Cheng, Y.; Breschi, A.; Vierstra, J.; Wu, W.; Ryba, T.; Sandstrom, R.; Ma, Z.; Davis, C.; Pope, B.D.; et al. A comparative encyclopedia of DNA elements in the mouse genome. Nature 2014, 515, 355-364. [CrossRef]

290. Chaturvedi, P.; Gilkes, D.M.; Takano, N.; Semenza, G.L. Hypoxia-inducible factor-dependent signaling between triple-negative breast cancer cells and mesenchymal stem cells promotes macrophage recruitment. Proc. Natl. Acad. Sci. USA 2014, 111, E2120-E2129. [CrossRef]

291. Lin, S.; Sun, L.; Hu, J.; Wan, S.; Zhao, R.; Yuan, S.; Zhang, L. Chemokine C-X-C motif receptor 6 contributes to cell migration during hypoxia. Cancer Lett. 2009, 279, 108-117. [CrossRef] [PubMed]

292. Ronkainen, V.P.; Tuomainen, T.; Huusko, J.; Laidinen, S.; Malinen, M.; Palvimo, J.J.; Ylä-Herttuala, S.; Vuolteenaho, O.; Tavi, P. Hypoxia-inducible factor 1-induced G protein-coupled receptor 35 expression is an early marker of progressive cardiac remodelling. Cardiovasc. Res. 2014, 101, 69-77. [CrossRef] [PubMed]

293. Chen, K.; He, L.; Li, Y.; Li, X.; Qiu, C.; Pei, H.; Yang, D. Inhibition of GPR35 Preserves Mitochondrial Function After Myocardial Infarction by Targeting Calpain 1/2. J. Cardiovasc. Pharmacol. 2020, 75, 556-563. [CrossRef] [PubMed]

294. Maravillas-Montero, J.L.; Burkhardt, A.M.; Hevezi, P.A.; Carnevale, C.D.; Smit, M.J.; Zlotnik, A. Cutting edge: GPR35/CXCR8 is the receptor of the mucosal chemokine CXCL17. J. Immunol. 2015, 194, 29-33. [CrossRef] [PubMed]

295. Binti Mohd Amir, N.A.S.; Mackenzie, A.E.; Jenkins, L.; Boustani, K.; Hillier, M.C.; Tsuchiya, T.; Milligan, G.; Pease, J.E. Evidence for the Existence of a CXCL17 Receptor Distinct from GPR35. J. Immunol. 2018, 201, 714-724. [CrossRef] [PubMed]

296. Park, S.J.; Lee, S.J.; Nam, S.Y.; Im, D.S. GPR35 mediates lodoxamide-induced migration inhibitory response but not CXCL17induced migration stimulatory response in THP-1 cells; is GPR35 a receptor for CXCL17? Br. J. Pharmacol. 2018, 175, 154-161. [CrossRef] [PubMed]

297. Albadari, N.; Deng, S.; Li, W. The transcriptional factors HIF-1 and HIF-2 and their novel inhibitors in cancer therapy. Expert Opin. Drug Discov. 2019, 14, 667-682. [CrossRef]

298. Moen, I.; Stuhr, L.E. Hyperbaric oxygen therapy and cancer-A review. Target Oncol. 2012, 7, $233-242$.

299. Wu, X.; Zhu, Y.; Huang, W.; Li, J.; Zhang, B.; Li, Z.; Yang, X. Hyperbaric Oxygen Potentiates Doxil Antitumor Efficacy by Promoting Tumor Penetration and Sensitizing Cancer Cells. Adv. Sci. 2018, 5, 1700859. [CrossRef]

300. Parmar, K.; Mauch, P.; Vergilio, J.A.; Sackstein, R.; Down, J.D. Distribution of hematopoietic stem cells in the bone marrow according to regional hypoxia. Proc. Natl. Acad. Sci. USA 2007, 104, 5431-5436. [CrossRef]

301. Takubo, K.; Goda, N.; Yamada, W.; Iriuchishima, H.; Ikeda, E.; Kubota, Y.; Shima, H.; Johnson, R.S.; Hirao, A.; Suematsu, M.; et al. Regulation of the HIF-1alpha level is essential for hematopoietic stem cells. Cell Stem Cell 2010, 7, 391-402. [CrossRef] [PubMed]

302. Winkler, I.G.; Barbier, V.; Wadley, R.; Zannettino, A.C.; Williams, S.; Lévesque, J.P. Positioning of bone marrow hematopoietic and stromal cells relative to blood flow in vivo: Serially reconstituting hematopoietic stem cells reside in distinct nonperfused niches. Blood 2010, 116, 375-385. [CrossRef] [PubMed]

303. Coleman, R.L.; Brady, M.F.; Herzog, T.J.; Sabbatini, P.; Armstrong, D.K.; Walker, J.L.; Kim, B.G.; Fujiwara, K.; Tewari, K.S.; O’Malley, D.M.; et al. Bevacizumab and paclitaxel-carboplatin chemotherapy and secondary cytoreduction in recurrent, platinum-sensitive ovarian cancer (NRG Oncology/Gynecologic Oncology Group study GOG-0213): A multicentre, open-label, randomised, phase 3 trial. Lancet Oncol. 2017, 18, 779-791. [CrossRef] 
304. Zhu, P.; Du, X.L.; Lu, G.; Zhu, J.J. Survival benefit of glioblastoma patients after FDA approval of temozolomide concomitant with radiation and bevacizumab: A population-based study. Oncotarget 2017, 8, 44015-44031. [CrossRef]

305. Oyer, J.L.; Gitto, S.B.; Altomare, D.A.; Copik, A.J. PD-L1 blockade enhances anti-tumor efficacy of NK cells. Oncoimmunology 2018, 7, e1509819. [CrossRef]

306. Ni, X.; Xing, Y.; Sun, X.; Suo, J. The safety and efficacy of anti-PD-1/anti-PD-L1 antibody therapy in the treatment of previously treated, advanced gastric or gastro-oesophageal junction cancer: A meta-analysis of prospective clinical trials. Clin. Res. Hepatol. Gastroenterol. 2020, 44, 211-222. [CrossRef]

307. Wang, J.; Hu, W.; Wang, K.; Yu, J.; Luo, B.; Luo, G.; Wang, W.; Wang, H.; Li, J.; Wen, J. Repertaxin, an inhibitor of the chemokine receptors CXCR1 and CXCR2, inhibits malignant behavior of human gastric cancer MKN45 cells in vitro and in vivo and enhances efficacy of 5-fluorouracil. Int. J. Oncol. 2016, 48, 1341-1352. [CrossRef]

308. Fu, S.; Chen, X.; Lin, H.J.; Lin, J. Inhibition of interleukin 8/C-X-C chemokine receptor 1,/2 signaling reduces malignant features in human pancreatic cancer cells. Int. J. Oncol. 2018, 53, 349-357.

309. Dufies, M.; Grytsai, O.; Ronco, C.; Camara, O.; Ambrosetti, D.; Hagege, A.; Parola, J.; Mateo, L.; Ayrault, M.; Giuliano, S.; et al New CXCR1/CXCR2 inhibitors represent an effective treatment for kidney or head and neck cancers sensitive or refractory to reference treatments. Theranostics 2019, 9, 5332-5346. [CrossRef]

310. Xu, M.; Jiang, H.; Wang, H.; Liu, J.; Liu, B.; Guo, Z. SB225002 inhibits prostate cancer invasion and attenuates the expression of BSP, OPN and MMP-2. Oncol. Rep. 2018, 40, 726-736. [CrossRef]

311. Dominguez, C.; McCampbell, K.K.; David, J.M.; Palena, C. Neutralization of IL-8 decreases tumor PMN-MDSCs and reduces mesenchymalization of claudin-low triple-negative breast cancer. JCI Insight. 2017, 2, e94296. [CrossRef] [PubMed]

312. Bilusic, M.; Heery, C.R.; Collins, J.M.; Donahue, R.N.; Palena, C.; Madan, R.A.; Karzai, F.; Marté, J.L.; Strauss, J.; Gatti-Mays, M.E.; et al. Phase I trial of HuMax-IL8 (BMS-986253), an anti-IL-8 monoclonal antibody, in patients with metastatic or unresectable solid tumors. J. Immunother. Cancer 2019, 7, 240. [CrossRef] [PubMed]

313. Aalinkeel, R.; Nair, B.; Chen, C.K.; Mahajan, S.D.; Reynolds, J.L.; Zhang, H.; Sun, H.; Sykes, D.E.; Chadha, K.C.; Turowski, S.G.; et al. Nanotherapy silencing the interleukin- 8 gene produces regression of prostate cancer by inhibition of angiogenesis. Immunology 2016, 148, 387-406. [CrossRef] [PubMed]

314. Miyake, M.; Furuya, H.; Onishi, S.; Hokutan, K.; Anai, S.; Chan, O.; Shi, S.; Fujimoto, K.; Goodison, S.; Cai, W.; et al. Monoclonal Antibody against CXCL1 (HL2401) as a Novel Agent in Suppressing IL6 Expression and Tumoral Growth. Theranostics 2019, 9, 853-867. [CrossRef]

315. Idorn, M.; Olsen, M.; Halldórsdóttir, H.R.; Skadborg, S.K.; Pedersen, M.; Høgdall, C.; Høgdall, E.; Met, Ö.; Thor Straten, P. Improved migration of tumor ascites lymphocytes to ovarian cancer microenvironment by CXCR2 transduction. Oncoimmunology 2017, 7, e1412029. [CrossRef]

316. Kremer, V.; Ligtenberg, M.A.; Zendehdel, R.; Seitz, C.; Duivenvoorden, A.; Wennerberg, E.; Colón, E.; Scherman-Plogell, A.H.; Lundqvist, A. Genetic engineering of human NK cells to express CXCR2 improves migration to renal cell carcinoma. J. Immunother. Cancer 2017, 5, 73. [CrossRef]

317. Broussas, M.; Boute, N.; Akla, B.; Berger, S.; Beau-Larvor, C.; Champion, T.; Robert, A.; Beck, A.; Haeuw, J.F.; Goetsch, L.; et al. A New Anti-CXCR4 Antibody That Blocks the CXCR4/SDF-1 Axis and Mobilizes Effector Cells. Mol. Cancer Ther. 2016, 15, 1890-1899. [CrossRef]

318. Reeves, P.M.; Abbaslou, M.A.; Kools, F.R.W.; Poznansky, M.C. CXCR4 blockade with AMD3100 enhances Taxol chemotherapy to limit ovarian cancer cell growth. Anticancer Drugs 2017, 28, 935-942. [CrossRef]

319. Luo, Y.; Azad, A.K.; Karanika, S.; Basourakos, S.P.; Zuo, X.; Wang, J.; Yang, L.; Yang, G.; Korentzelos, D.; Yin, J.; et al. Enzalutamide and CXCR7 inhibitor combination treatment suppresses cell growth and angiogenic signaling in castration-resistant prostate cancer models. Int. J. Cancer 2018, 142, 2163-2174. [CrossRef]

320. Zhou, K.X.; Xie, L.H.; Peng, X.; Guo, Q.M.; Wu, Q.Y.; Wang, W.H.; Zhang, G.L.; Wu, J.F.; Zhang, G.J.; Du, C.W. CXCR4 antagonist AMD3100 enhances the response of MDA-MB-231 triple-negative breast cancer cells to ionizing radiation. Cancer Lett. 2018, 418, 196-203. [CrossRef]

321. Bockorny, B.; Semenisty, V.; Macarulla, T.; Borazanci, E.; Wolpin, B.M.; Stemmer, S.M.; Golan, T.; Geva, R.; Borad, M.J.; Pedersen, K.S.; et al. BL-8040, a CXCR4 antagonist, in combination with pembrolizumab and chemotherapy for pancreatic cancer: The COMBAT trial. Nat. Med. 2020, 26, 878-885. [CrossRef] [PubMed]

322. D'Alterio, C.; Zannetti, A.; Trotta, A.M.; Ieranò, C.; Napolitano, M.; Rea, G.; Greco, A.; Maiolino, P.; Albanese, S.; Scognamiglio, G.; et al. New CXCR4 Antagonist Peptide R (Pep R) Improves Standard Therapy in Colorectal Cancer. Cancers 2020, $12,1952$. [CrossRef] [PubMed]

323. Zhou, J.; Le, K.; Xu, M.; Ming, J.; Yang, W.; Zhang, Q.; Lu, L.; Xi, Z.; Ruan, S.; Huang, T. CXCR4 Antagonist AMD3100 Reverses the Resistance to Tamoxifen in Breast Cancer via Inhibiting AKT Phosphorylation. Mol. Ther. Oncolytics 2020, 18, 161-170. [CrossRef]

324. Vela, M.; Bueno, D.; González-Navarro, P.; Brito, A.; Fernández, L.; Escudero, A.; Valentín, J.; Mestre-Durán, C.; Arranz-Álvarez, M.; Pérez de Diego, R.; et al. Anti-CXCR4 Antibody Combined with Activated and Expanded Natural Killer Cells for Sarcoma Immunotherapy. Front. Immunol. 2019, 10, 1814. [CrossRef] [PubMed]

325. Li, Z.; Wang, Y.; Shen, Y.; Qian, C.; Oupicky, D.; Sun, M. Targeting pulmonary tumor microenvironment with CXCR4-inhibiting nanocomplex to enhance anti-PD-L1 immunotherapy. Sci. Adv. 2020, 6, eaaz9240. [CrossRef] [PubMed] 
326. Oriuchi, N.; Aoki, M.; Ukon, N.; Washiyama, K.; Tan, C.; Shimoyama, S.; Nishijima, K.I.; Takahashi, K.; Ito, H.; Ikezoe, T.; et al. Possibility of cancer-stem-cell-targeted radioimmunotherapy for acute myelogenous leukemia using 211At-CXCR4 monoclonal antibody. Sci. Rep. 2020, 10, 6810. [CrossRef] [PubMed]

327. Chittasupho, C.; Anuchapreeda, S.; Sarisuta, N. CXCR4 targeted dendrimer for anti-cancer drug delivery and breast cancer cell migration inhibition. Eur. J. Pharm. Biopharm. 2017, 119, 310-321. [CrossRef]

328. Céspedes, M.V.; Unzueta, U.; Aviñó, A.; Gallardo, A.; Álamo, P.; Sala, R.; Sánchez-Chardi, A.; Casanova, I.; Mangues, M.A.; Lopez-Pousa, A.; et al. Selective depletion of metastatic stem cells as therapy for human colorectal cancer. EMBO Mol. Med. 2018, 10, e8772. [CrossRef]

329. Herrmann, K.; Schottelius, M.; Lapa, C.; Osl, T.; Poschenrieder, A.; Hänscheid, H.; Lückerath, K.; Schreder, M.; Bluemel, C.; Knott, M.; et al. First-in-Human Experience of CXCR4-Directed Endoradiotherapy with 177Lu- and 90Y-Labeled Pentixather in Advanced-Stage Multiple Myeloma with Extensive Intra- and Extramedullary Disease. J. Nucl. Med. 2016, 57, 248-251. [CrossRef]

330. Bhatia, S.; O’Bryan, S.M.; Rivera, A.A.; Curiel, D.T.; Mathis, J.M. CXCL12 retargeting of an adenovirus vector to cancer cells using a bispecific adapter. Oncolytic Virother. 2016, 5, 99-113. [CrossRef]

331. Taslimi, Y.; Zahedifard, F.; Habibzadeh, S.; Taheri, T.; Abbaspour, H.; Sadeghipour, A.; Mohit, E.; Rafati, S. Antitumor Effect of IP-10 by Using Two Different Approaches: Live Delivery System and Gene Therapy. J. Breast Cancer 2016, 19, 34-44. [CrossRef] [PubMed]

332. Hu, Z.; Chen, J.; Zhou, S.; Yang, N.; Duan, S.; Zhang, Z.; Su, J.; He, J.; Zhang, Z.; Lu, X.; et al. Mouse IP-10 Gene Delivered by Folatemodified Chitosan Nanoparticles and Dendritic/tumor Cells Fusion Vaccine Effectively Inhibit the Growth of Hepatocellular Carcinoma in Mice. Theranostics 2017, 7, 1942-1952. [CrossRef] [PubMed]

333. Han, X.; Wang, Y.; Sun, J.; Tan, T.; Cai, X.; Lin, P.; Tan, Y.; Zheng, B.; Wang, B.; Wang, J.; et al. Role of CXCR3 signaling in response to anti-PD-1 therapy. EBioMedicine 2019, 48, 169-177. [CrossRef] [PubMed]

334. Moon, E.K.; Wang, L.S.; Bekdache, K.; Lynn, R.C.; Lo, A.; Thorne, S.H.; Albelda, S.M. Intra-tumoral delivery of CXCL11 via a vaccinia virus, but not by modified T cells, enhances the efficacy of adoptive T cell therapy and vaccines. Oncoimmunology 2018, 7, e1395997. [CrossRef]

335. Zhao, M.; Ma, Q.; Xu, J.; Fu, S.; Chen, L.; Wang, B.; Wu, J.; Yang, L. Combining CXCL10 gene therapy and radiotherapy improved therapeutic efficacy in cervical cancer HeLa cell xenograft tumor models. Oncol. Lett. 2015, 10, 768-772. [CrossRef]

336. Wu, X.; Sun, A.; Yu, W.; Hong, C.; Liu, Z. CXCL10 mediates breast cancer tamoxifen resistance and promotes estrogen-dependent and independent proliferation. Mol. Cell Endocrinol. 2020, 512, 110866. [CrossRef]

337. Ma, J.J.; Jiang, L.; Tong, D.Y.; Ren, Y.N.; Sheng, M.F.; Liu, H.C. CXCL13 inhibition induce the apoptosis of MDA-MB-231 breast cancer cells through blocking CXCR5/ERK signaling pathway. Eur. Rev. Med. Pharmacol. Sci. 2018, 22, 8755-8762.

338. Matsumura, S.; Demaria, S. Up-regulation of the pro-inflammatory chemokine CXCL16 is a common response of tumor cells to ionizing radiation. Radiat. Res. 2010, 173, 418-425. [CrossRef] 